



\title{
New Brachiopoda from the Indian Ocean
}

\author{
G. Arthur Cooper
}

\section{ISLEDS}

FE⿺ 141979

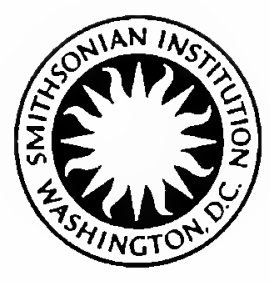

SMITHSONIAN INSTITUTION PRESS

City of Washington

1973 


\begin{abstract}
A B S T R A C T
G. Arthur Cooper. New Brachiopoda from the Indian Ocean. Smithsonian Contributions to Paleobiology, number 16, 45 pages, 1 figure, 8 plates. 1973.-The collections described in this paper add significantly to the brachiopod fauna. Most of the specimens were collected on the following cruises of the Woods Hole Oceanographic research vessel Anton Bruun while participating in the biological program of the International Indian Ocean Expedition: Cruise 1, east side of the Indian Ocean and Andaman Sea; Cruise 4B, off the Gulf of Cutch in the Arabian Sea; Cruises 7 and 8, in the Mozambique Channel and off the east coast of Africa; and Cruise 9, off the east coast of the Somali Republic. Of the fifteen species in the Anton Bruun collection, nine are described as new. Three of the new species represent new genera. In addition to these a fourth new genus is based on Rhynchonella valdiviae Helmcke from the southern Indian Ocean, and a rare new species of Argyrotheca is described from the Red Sea. Species described but poorly figured by W. H. Dall also are discussed and illustrated in this paper. Available pertinent geographical and ecological data are recorded and discussed. Although Mediterranean and Atlantic brachiopod elements have been known from the Indian Ocean, the Anton Bruun collections produced two genera hitherto found only in Pacific waters.
\end{abstract}

OfFICIAL PUBLICATION DATE is handstamped in a limited number of initial copies and is recorded in the Institution's annual report, Smithsonian Year. SI Press Number 4788. SFries Cover Design: The trilobite Phacops rana Green.

Library of Congress Cataloging in Publication Data.

Cooper, Gustav Arthur, 1902-

New Brachiopoda from the Indian Ocean.

(Smithsonian contributions to paleobiology no. 16)

Bibliography: $p$.

1. Brachiopoda-Indian Ocean. 1. Title. II. Series: Smithsonian Institution. Smithsonian

contributions to paleobiology, no. 16 .

QE701.S56 no. 16 [QL395] 591'.08s [595'.32'09165] $72-8960$

For sale by the Superintendent of Documents, U.S. Government Printing Office

Washington, D.C. 20402 price $\$ 1.00$ (paper cover) 


\title{
New Brachiopoda from the Indian Ocean
}

\author{
G. Arthur Cooper
}

The current intensified interest in the modern oceans is leading to a greater knowledge of modern brachiopods. These have been hitherto regarded as a rare and insignificant part of the present invertebrate fauna of the oceans. They are abundant in places in the Arctic seas (Foster 1968) and outnumber other members of the mega fauna. The result of these dredgings and studies will greatly extend our list of recent brachiopod species and genera.

Although 41 species and 25 genera of brachiopods have been described from the Indian Ocean, most of these were taken from a few areas. The collection described herein, mostly collected on cruises of the Anton Bruun, adds significantly to the brachiopod fauna. The collection also supplies information on the little known brachiopods from the Mozambique Channel and the waters on the north side of Madagascar. The new discoveries tend to strengthen the ties of the Indian Ocean brachiopod fauna to that of the Mediterranean and parts of the Atlantic, but also indicate some unsuspected connections to the Pacific realm.

Brachiopod localities are widely scattered in the Indian Ocean. In the northern part the waters around the Maldive Islands have yielded four genera and species, but the largest number of brachiopods has been taken from the waters around several islands in the extreme southern part of the

G. Arthur Cooper, Department of Paleobiology, Smithsonian Institution, Washington, D. C. 20560. ocean: Prince Edward, Marion, Kerguelen (the most prolific area), St. Paul, and Heard Islands. These combined have produced 10 genera and 14 species.

ACKNOWLEDGMENTs. -I acknowledge with thanks the help of Drs. R. E. Grant and M. W. Foster, who read the manuscript and offered helpful suggestions.

Places in the Indian Ocean from which brachiopods have been taken and their species are:

KARACHI-ARABIAN SEA

Lingula murphiana Reeve

*L. translucida Dall

$$
\text { BOMBAY }
$$

Lingula hians Swainson

$$
\text { CEYLON }
$$

Lingula murphiana Reeve

* Discinisca indica Dall

$$
\text { OFF SOUTHWEST TIP OF INDIA }
$$

Frenulina (=Compsoria) alcocki (Joubin)

$$
\text { MALDIVE ISLANDS }
$$

Cryptopora maldivensis Muir-Wood Chlidonophora chuni (Blochmann)

Dyscolia johannis-davisi (Alcock)

Dallithyris murrayi Muir-Wood

SAYA DE MALHA BANK

Rhytirhynchia sladeni (Dall)

Dallithyris murrayi Muir-Wood

* Kraussina gardineri Dall 


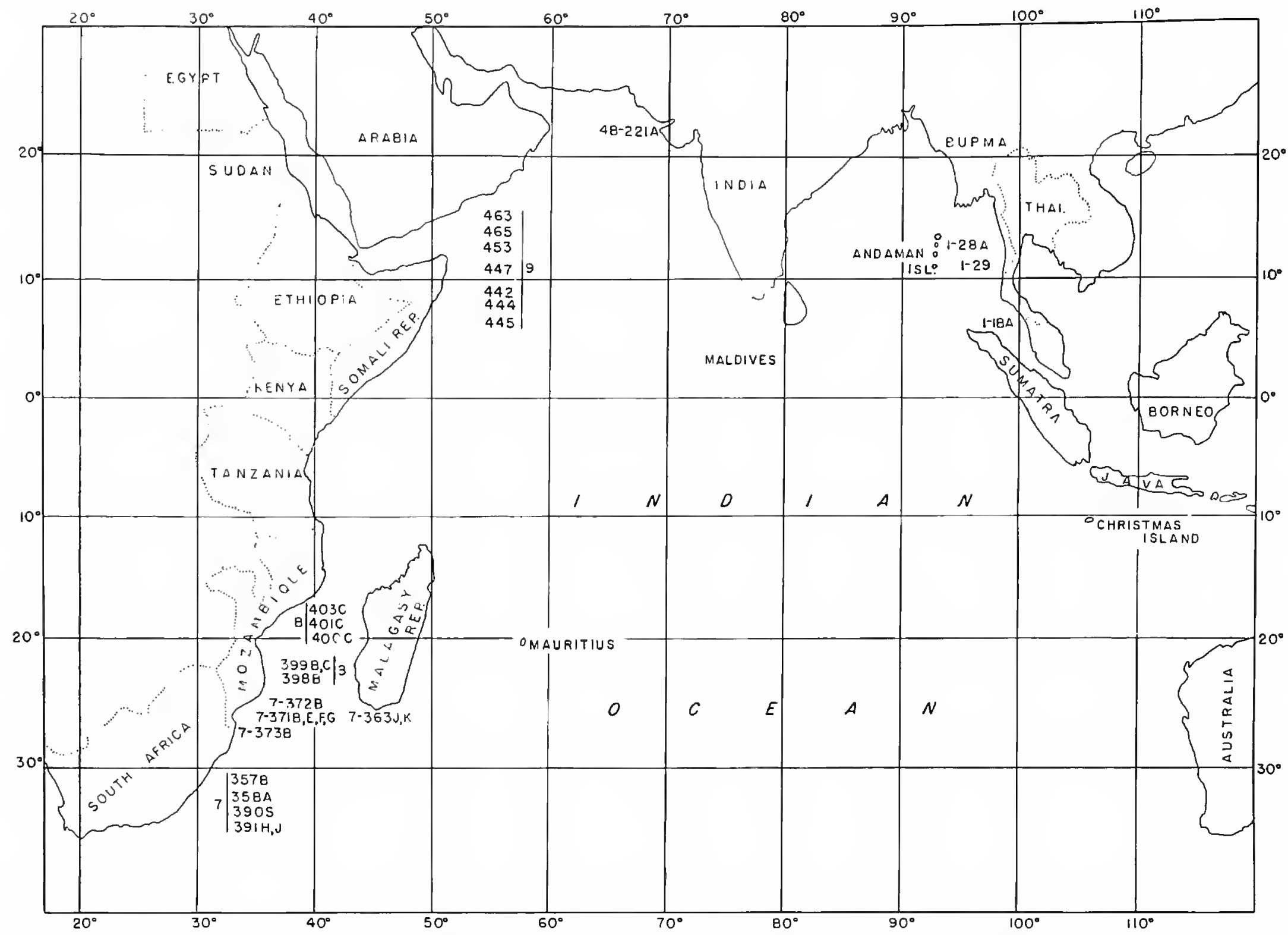

Figure 1.-Outline map of the Indian Ocean showing locations of cruises and their dredging stations that produced brachiopods.

REUNION ISLAND

***Pantellaria gigantia (Deshayes) = Megerlia echinata Fischer and Oehlert

\section{MAURITIUS ISLAND}

* Lacazella mauritiana (Dall)

Dallithyris (?) cernica Crosse

Megerlina pisum (Lamarck)

Megerlia truncata (Linnaeus)

\section{OFF ZANZIBAR}

Lingula unguis (Linnaeus)

Leptothyrella ignota Muir-Wood

CHRISTMAS ISLAND

\section{* Thecidellina blochmanni Dall}

EAST COAST OF AFRICA

Lingula murphiana Reeve

L. aff. L. exusta Reeve
Cryplopora boettgeri Helmke

Agulhasia davidsoni W. King

Terebratulina abyssicola (Adams and Reeve)

Kraussina natalensis (Krauss)

Megerlina pisum (Lamarck)

K. rubra (Pallas)

south COAst of AFrica (east of Cape Agulhas)

Agulhasia davidsoni W. King

Terebratulina abyssicola (Adams and Reeve)

$T$. meridionalis Jackson

Gryphus capensis Jackson

Liothyrella agulhasensis (Helmcke)

Megerlia echinata (Fischer and Oehlert)

Megerlina capensis (Adams and Reeve)

M. striata Jackson

Kraussina cognala (Sowerby)

K. crassicosla Jackson

K. rubra (Pallas)

* Terebratella rubiginosa Dall 
PRINCE EDWARD ISLAND

Platidia anomioides (Scacchi and Philippi)

MARION ISLAND

Terebratulina meridionalis Jackson

ST. PAUL ISLAND

Crania valdiviae Helmcke

Valdiviathyris quensted $1 i$ Helmcke

Megerlina davidsoni (Vélain)

Liothyrella winteri (Blochmann)

AMSTERDAM ISLAND

Rhynchonella (=Striarina) valdiviae Helmcke

KERGUELEN ISLAND

Eucalathis murrayi (Davidson)

Liothyrella winteri (Blochmann)

L. moseleyi (Davidson)

Terebratella enzenspergeri Blochnann

Magellania kerguelensis (Davidson)

HEARD ISLAND

Notosaria pjxidata (Davidson)

OFF NIAS ISLAND, SUMATRA

Terebratulina valdiviae Blochmann

PERSIAN GULF

Terebratulina caputserpentis abbreviata Jackson

Megerlia truncata paucistriata Jackson

*Described or figured herein.

* Southwest of the Cape of Good Hope, latitude $36^{\circ}$ $43^{\prime} 5^{\prime \prime}$, longitude $13^{\circ} 36^{\prime} \mathrm{E}$ in Atlantic waters.

***See discussion of this species.

The new material from the Indian Ocean collected by the Anton Bruun was taken from 31 stations in widely scattered groups. Three are from the Andaman Sea; one from the Arabian Sea; seven from the Gulf of Arabia near its junction with the Indian Ocean south and southwest of Cape Guardafui, Somali Republic; twenty from the east coast of Africa off Natal, Mozambique and the Mozambique Channel; and two from the Red Sea. Most of the lots are small and only fifteen species and genera are represented. Although the entire collection is small it includes one genus, Argyrotheca, hitherto not represented in the Indian Ocean brachiopod fauna and three new genera. Nine new species are described from the Anton Bruun material.
In addition to the Anton Bruun material a number of species already described from the Indian Ocean are discussed and figured. These are mostly species described but never illustrated by Dall (1920) and a species described by Joubin but never illustrated by photographs. New specimens from the Red Sea are also included.

The species and genera collected by the Anton Bruun are listed as follows:

\section{CRUISE 1}

Station $18 \mathrm{~A}$, latitude $07^{\circ} 34^{\prime} \mathrm{N}$, longitude $98^{\circ} 00^{\prime} \mathrm{E}$, at 77 meters in the Andaman Sea off Thailand.

Thaumatosia anomala, new species

Terebratulina species 1

Compsoria species

Station $28 \mathrm{~A}$, latitude $11^{\circ} 52^{\prime} \mathrm{N}$, longitude $92^{\circ} 49^{\prime} \mathrm{E}$, at 66 meters off the Andaman Islands, Andaman Sea.

Cryptopora curiosa, new species.

Station 29 , latitude $11^{\circ} 23^{\prime} \mathrm{N}$, longitude $93^{\circ} 31^{\prime} \mathrm{E}, 40-55$ meters off the Andaman Islands, Andaman Sea.

Thanmatosia anomala, new species

\section{CRUISE: $4 \mathrm{~B}$}

Station $221 \mathrm{~A}$, latitude $22^{\circ} 32^{\prime} \mathrm{N}$, longitude $67^{\circ} 07^{\prime} \mathrm{E}$ to $22^{\circ} 31^{\prime} \mathrm{N}, 68^{\circ} 05^{\prime} \mathrm{E}$, at 57 meters, off the Gulf of Cutch, east side Arabian Sea.

Discinisca species

\section{CRUISF, 7}

Station $357 \mathrm{~B}$, latitude $29^{\circ} 11^{\prime} \mathrm{S}$, longitude $32^{\circ} 02^{\prime} \mathrm{E}, 86$ meters $(37-38$ fms) off north Natal, vicinity of Durban, South Africa.

Terebratulina species

Station $358 \mathrm{~A}$, latitude $29^{\circ} 19^{\prime} \mathrm{S}$, longitude $32^{\circ} 00^{\prime} \mathrm{E}$, at 366 meters (200 fms) Durban Bay, South Africa.

Cryptopora boettgeri Helmcke

Agnlhasia davidsoni W. King

Grypluts africanus, new species

Terebratulina species

Kraussina species

Station $363 \mathrm{~J}$, latitude $23^{\circ} 36^{\prime} \mathrm{S}$, longitude $43^{\circ} 24^{\prime} \mathrm{E}$, at 1280 ineters, southeastern Mozambique Channel, Tulear, Malagasy Republic.

Chlidonophora chuni Blochmann

Station $363 \mathrm{~K}$, latitude $23^{\circ} 34^{\prime} \mathrm{S}$, longitude $43^{\circ} 25^{\prime} \mathrm{E}$, at 1080-1280 meters, southeastern Mozambique Channel, Tulear, Malagasy Republic.

Eucalathis fasciculata, new species

Station $37 \mathrm{E}$, latitude $24^{\circ} 46^{\prime} \mathrm{S}$, longitude $35^{\circ} 20^{\prime} \mathrm{E}$, at 132 meters off Mozambique, northeast of Lourenco Marques. 
Megerlina species

Compsoria suffusa, new species

Station $371 \mathrm{~F}$, latitude $24^{\circ} 46^{\prime} \mathrm{S}$, longitude $35^{\circ} 18^{\prime} \mathrm{E}$, off Mozambique at 110 meters, northeast of Lourenco Marques. Terebratulina species

Frenulina cruenta, new species

Compsoria suffusa, new species

Station $371 \mathrm{G}$, latitude $24^{\circ} 49^{\prime} \mathrm{S}$, longitude $35^{\circ} 13^{\prime} \mathrm{E}$, at 73 meters, off Mozambique, northeast of Lourenco Marques.

Cryptopora curiosa, new species

Station $372 \mathrm{~B}$, latitude $24^{\circ} 48^{\prime} \mathrm{S}$, longitude $35^{\circ} 59^{\prime} \mathrm{E}$, at 42 meters, off Mozambique, northeast of Lourenco Marques.

Terebralulina abyssicola (Adams and Reeve)

Station $373 \mathrm{~B}$, latitude $26^{\circ} 00^{\prime} \mathrm{S}$, longitude $33^{\circ} 05^{\prime} \mathrm{E}$, at 135 meters off Mozambique, at Lourenco Marques.

Compsoria suffusa, new species

Station $390 \mathrm{~S}$, latitude $29^{\circ} 35^{\prime} \mathrm{S}$, longitude $31^{\circ} 42^{\prime} \mathrm{E}$, at 138 meters off Durban, South Africa.

Fragment?

Station $391 \mathrm{H}$, latitude $29^{\circ} 21^{\prime} \mathrm{S}$, longitude $31^{\circ} 35^{\prime} \mathrm{E}$, at 57 meters, off Durban, South Africa.

Agulhasia davidsoni King

Station $391 \mathrm{~J}$, latitude $29^{\circ} 21^{\prime} \mathrm{S}$, longitude $31^{\circ} 35^{\prime} \mathrm{E}$, at 57 meters, Durban, South Africa.

Agulhasia davidsoni W. King

CRUISE 8

Station $398 \mathrm{~B}$, latitude $22^{\circ} 25^{\prime} \mathrm{S}$, longitude $35^{\circ} 54^{\prime} \mathrm{E}$ at 740 meters, off Mozambique, off Cabo Sao Sebastiao.

Nipponithyris afra, new species

Station $399 \mathrm{~B}$, latitude $22^{\circ} 30^{\prime} \mathrm{S}$, longitude $36^{\circ} 07^{\prime} \mathrm{E}$ at $851-$ 960 meters, off Mozambique, off Cabo Sao Sebastiao, Mozam. bique.

Nipponithyris afra, new species

Station $399 \mathrm{C}$, latitude $21^{\circ} 18^{\prime} \mathrm{S}$, longitude $36^{\circ} 18^{\prime} \mathrm{E}$, at 1510-1600 meters off Mozambique, north of Cabo Sao Sebastiao, Mozambique.

Chlidonophora chuni Blochmann

Station $400 \mathrm{C}$, latitude $20^{\circ} 30^{\prime} \mathrm{S}$, longitude $35^{\circ} 43^{\prime} \mathrm{E}$, at 62 meters, off Mozambique, off Beira.

Terebralulina meridionalis Jackson

Station $401 \mathrm{C}$, latitude $19^{\circ} 51^{\prime} \mathrm{S}$, longitude $36^{\circ} 21^{\prime} \mathrm{E}$, at 62 meters, off Beira, Mozambique.

Compsoria suffusa, new species (?)

Station $403 \mathrm{C}$, latitude $19^{\circ} 09^{\prime} \mathrm{S}$, longitude $36^{\circ} 55^{\prime} \mathrm{E}$, at 88 meters, in the Mozambique Channel, off Beira, Mozambique.

Compsoria species?
Station $403 \mathrm{E}$, latitude $19^{\circ} 09^{\prime} \mathrm{S}$, longitude $36^{\circ} 55^{\prime} \mathrm{E}$, at 88 meters, in the Mozambique Channel, off Beira, Mozambique.

Compsoria suffusa, new species

\section{CRUISE 9}

Station 442 , latitude $09^{\circ} 33^{\prime} \mathrm{N}$ to $09^{\circ} 36^{\prime} \mathrm{N}$, longitude $50^{\circ} 09^{\prime} \mathrm{E}$ to $51^{\circ} 01^{\prime} \mathrm{E}$, at 79 meters at the northeast end of the Somali Republic.

Frenulina cruenta, new species

Station 444 , latitude $09^{\circ} 36^{\prime} \mathrm{N}$ to $09^{\circ} 40^{\prime} \mathrm{N}$, longitude $51^{\circ} 01^{\prime} \mathrm{E}$ to $51^{\circ} 03^{\prime} \mathrm{E}$, at 80 meters, at the northeast end of the Somali Republic.

Cryptopora curiosa, new species

Terebralulina species 2

Argyrotheca somaliensis, new species

Frenulina cruenta Cooper, new species

Station 445 , latitude $09^{\circ} 41^{\prime} \mathrm{N}$ to $09^{\circ} 43^{\prime} \mathrm{N}$, longitude $51^{\circ} 03^{\prime} \mathrm{E}$ to $51^{\circ} 04^{\prime} \mathrm{E}$ at 65 meters, off the northeast end of the Somali Republic.

Terebratulina species 2

Gryphus indianensis, new species

Argyrotheca somaliensis, new species

Frenulina cruenta, new species

Station 447 , latitude $10^{\circ} 00^{\prime} \mathrm{N}$ to $10^{\circ} 03^{\prime} \mathrm{N}$, longitude $51^{\circ} 15^{\prime} \mathrm{E}$ to $51^{\circ} 15^{\prime} \mathrm{E}$, at 59-61 meters, off the northeast end of the Somali Republic.

Cryptopora curiosa, new species

Argyrotheca somaliensis, new species

Frenulina cruenta, new species

Station 453 , latitude $11^{\circ} 11^{\prime} \mathrm{N}$ to $11^{\circ} 15^{\prime} \mathrm{N}$, longitude $51^{\circ} 14^{\prime} \mathrm{E}$ to $51^{\circ} 12^{\prime} \mathrm{E}$ at $47-49$ meters off northeast end of the Somali Republic.

Discinisca, new species

Station 463 , latitude $11^{\circ} 24^{\prime} \mathrm{N}$ to $11^{\circ} 29^{\prime} \mathrm{N}$, longitude $51^{\circ} 35^{\prime} \mathrm{E}$ to $51^{\circ} 36^{\prime} \mathrm{E}$, at $75-175$ meters (mostly 150 meters) off northeast end of the Somali Republic.

Terebralulina species

Compsoria species

Station 465 , latitude $11^{\circ} 37^{\prime} \mathrm{N}$, longitude $51^{\circ} 27^{\prime}$, at 67-72 meters southeast of Cape Guardafui, Somali Republic.

Cryptopora curiosa, new species

Gryphus indianensis, new species

Frenulina cruenta, new species

RED SEA

From a reef cave, reef Ras Muhammad, southernmost Sinai Peninsula from a depth of less than 10 meters.

Argyrotheca jacksoni Cooper, new species

Megerlia echinata (Fischer and Oehlert) 
Class INARTICULATA Huxley, 1869

Order LINGULIDA Waagen, 1885

Superfamily LINGULACEA Menke, 1828

Family LINGULIDAE Menke, 1828

Genus Lingula Bruguiere, 1797

Several species of Lingula have been identified from the Indian Ocean (Muir-Wood 1959:288), some of uncertain identity but others better known. Lingula translucida Dall from Java, part unknown, is identified from Karachi. There are only four specimens from Karachi and all are larger than Dall's types, one of them fully twice as large. Except for the lustrous exterior, the shapes of the Karachi specimens are not in accordance with those from Java. The latter are rounded anteriorly whereas the Pakistan specimens are truncated. Larger collections from both places will be necessary in order to settle the true identity of the species. Dall also described a Discinisca from the vicinity of Bombay. Still another species was taken by the Anton Bruun (Cruise 9) from off the northeast coast of the Somali Republic. An abundance of specimens was taken and they will be described by Dr. S. H. Chuang, University of Singapore. Pelagodiscus larvae were reported from the Indian Ocean (Muir-Wood 1959:287; Helmcke 1940:230). Geographically this genus is said to be the most widely spread brachiopod known in the oceans today (Zezina, 1965). Dall's species are figured for the first time herein.

\section{Lingula translucida Dall}

Plate 1: figurfs 10-13; Plate 4: figures 15, 16

Lingula translucida Dall, 1920:264.

Of the two specimens marked as types by Dall, the larger one, USNM 174003a, is chosen as lectotype. The specimens from Karachi, Pakistan, referred to this species are shaped differently and do not appear conspecific. The type is from Java and that is the only locality information given.

TYPEs.-Lectotype: USNM 174003a; paratype: USNM 174003b.
Order ACROTRETIDA Kuhn, 1949

Superfamily DISCINACEA Gray, 1840

Family ORBICULOIDEIDAE Schuchert and Levene, 1929

Subfamily DISCINISCINAE Schuchert and Levene, 1929

Genus Discinisca Dall, 1871

Discinisca indica Dall

Plate 1: figures 18-25

Discinisca indica Dall, 1920:279.

The collection consists of eleven specimens, four with parts of the ventral valve in position, the others consisting of dorsal valves only. Of the four with ventral valves, one is about twice as large as the other three and is chosen as lectotype.

The locality is given as Bombay, India.

TYPES.-Lectotype: USNM 90305b; figured paratypes: USNM 90305a, c, d; unfigured paratypes: USNM $90305 \mathrm{e}-\mathrm{k}$.

\section{Class ARTICULATA Huxley, 1869}

\section{Order RHYNCHONELLIDA Kuhn, 1949}

\section{Superfamily RHYNCHONELLACEA Gray, 1848}

Rhynchonellida are rare in the Indian Ocean. Only four genera have been found: Cryptopora, Notosaria, Rhytirhynchia, and Striarina. The first is known from two species and a third is added herein. The second occurs at Kerguelen Island and was described by Davidson as a variety of Rhynchonella nigricans Sowerby $[=$ Notosaria $]$. The third is known from two specimens only and was originally described as a species of Hemithiris. The fourth occurs at St. Paul Island where it is known from several specimens. It was originally described by Helmcke as Rhynchonella valdiviae. The rarity of Rhynchonellida in the Indian Ocean reflects the general decline of this group of brachiopods from the Tertiary into the Recent.

Most of these rhynchonellids occur in water deeper than 200 meters but Cryptopora has a wide depth tolerance. One of its species, C. gnomon (Jeffreys) of the North Atlantic, occurs in very deep 
water of 3257 meters. Of the two Indian Ocean species reported herein, $C$. boettgeri Helmcke is usually in deep waters but $C$. curiosa, new species, lives in water less than 200 meters deep. The other Indian Ocean species, C. maldivensis Muir-Wood, occurs in 933 meters. The deep-sea forms usually (lo not have the elaborate deltidial structures seen on the shallow-water species, $C$. curiosa and $C$. rectimarginata Cooper.

\section{Family CRYPTOPORIDAE Muir-Wood, 1955}

\section{Genus Cryptopora Jeffreys, 1869}

\section{Cryptopora boettgeri Helmcke}

Cryptopora boettgeri Helmcke, 1939:245, fig. 251; 1940:286, fig. 35.-Muir-Wood, 19:39:292.

This species is readily distinguished from $C$. $\mathrm{cu}$ riosa, new species, in its general shape, lack of capillae on the exterior, and the nodes on the beak ridges in young specimens. Internally the median septum is shorter and narrow: at its extremity. Deltidial plates are long and narrow but are set at a high angle, while the apical plate is very short. This extencls the range of the species considerably east of its original discovery on the Agulhas Bank.

LoGality.-Anton Bruun Cruise 7, station 358A.

TrPes.-Mentioned specimens: USNM 550350.

\section{Cryptopora curiosa, new species}

Plati: 1: figures 4-6; Plate 2: figures 1-25

Cryptopora sp.-Muir-Wood, 1959:294, pl. 5: fig. 11.

Small, roundly triangular in outline; sides and anterior margin well rounded; posterolateral margins forming an angle of about $90^{\circ}$; lenticular in profile with the two valves of about equal depth; anterior commissure rectimarginate or with a very slight dorsad wave; beak long, nearly straight to suberect; foramen small, hypothyridid (?); deltidial plates disjunct but obscure, fared laterally into thick, rounded wings; apical plate long and thin. Surface finely and minutely capillate, the capillae often cancellated by numerous fairly strong concentric growth lines. Shell thin and transparent. Pedicle thin and moderately long.

Ventral valve unevenly convex in lateral profile, the posterior third having the greater convexity and the anterior third somewhat flattened. Anterior profile a low, broad, flattened dome with short, steep sides. Umbonal region narrowly convex, the convexity dissipating toward midvalve; anterior slope flat or with a broad, faint sulcus; sides convex and with gentle slopes.

Dorsal valve evenly and gently convex in lateral and anterior profiles; umbonal and median regions moderately swollen; anterior slope slightly inflated; lateral slopes convex, gently sloping.

Ventral valve interior with strong, vertical dental plates supporting small, sharp teeth; myophragm poorly developed, low and thick.

Dorsal valve interior with apical margin thickened and roughened to serve as a cardinal process; ridges thin and upright, located on the posteroventral edge of the crura; crura moderately long, slightly outwardly bowed, maniculifer in form but with flattened tips not strongly serrate. Median septum short, not reaching the apex, rising at a steep angle to about midvalve; crest narrow, truncated; anterior edge forming an elongate $S$.

Lophophore circinate with long cirri extending to the shell margin. Setae numerous, very fine.

Measurements in millimeters:

\begin{tabular}{lccccc} 
USNM & \multicolumn{5}{c}{$\begin{array}{c}\text { Dorsal } \\
\text { valve }\end{array}$} \\
specimen & Length & Mength & width & Thickness & $\begin{array}{c}\text { Apical } \\
\text { angle }\end{array}$ \\
550364 & 3.8 & 3.0 & 2.9 & 1.1 & $85^{\circ}$ \\
550362 & 3.0 & 2.4 & 2.4 & $0.7 ?$ & $88^{\circ}$ \\
$550363 \mathrm{a}$ & 2.4 & 1.9 & 2.0 & 0.6 & $88^{\circ}$
\end{tabular}

Diagnosis.-Cryptopora with elaborate growths on the delthyrial margin.

TYPES.-Holotype: USNM 550364. Figured paratypes: USNM 550360; 55036la, b; 550362; 550363a, b; 550364 .

Localities. -Anton Bruun Cruise 1, station 28A; Anton Bruun Cruise 7, station 37IG; Anton Bruun Cruise 9, stations 444, 447, 465.

Comparison.-This species differs from all described Cryptoporas in the elaborate development of the deltidial region. In outline it is similar to C. maldivensis Muir-Wood (1959) but does not have a cardinal process like that described by MuirWood, nor does it have the axe-shaped septum figured by her. It does not have the strongly serrate distal end of the crura as noted in C. maldivensis. Furthermore $C$. maldivensis has narrow deltidial 
plates and no apical plate if one can judge by the length of the pedicle and its emergence at the apex.

Cryptopora curiosa differs from $C$. boettgeri Helmcke not only in the aforesaid beak characters but also in having smooth posterolateral margins. Helmcke's species is characterized by a row of nodes along these margins.

Cryptopora rectimarginata Cooper has elaborate winglike plates on the delthyrial margins, but they are much less complicated than those from the Indian Ocean. The Floricla species also has an apical plate that restricts the pedicle opening.

\section{Family HEMITHYRIDIDAE Rzhonsnitzkaya, 1956}

\section{Genus Notosaria Cooper, 1959}

\section{Notosaria pyxidata (Davidson)}

Rhynchonella nigricans var. pyxidata Davidson, 1880:59, pl. 4: fig. 14; 1887:170, pl. 24: fig. 20.

The illustration of this species in Davidson (1880) is of a fairly coarsely ribbed shell with low beak, but the illustrations in 1887 are sufficiently different to be of a different specimen or species. The latter illustrations suggest a shell much more finely ornamented and with a more elongated and erect beak with larger and more open foramen. Figure $14 c$ of the first publication showing the lines that produce an "imbricating appearance" is not repeated in the second publication.

Through the kindness of Dr. C. H. Brunton and The British Museum (Natural History) a specimen was loaned for study. Although the interior details were not available, the exterior characters of this specimen were those of Notosaria.

Family BASILIOLIDAE Cooper, 1959

Subfamily BASILIOLINAE Cooper, 1959

Genus Rhytirhynchia Cooper, 1959

\section{Rhytirhynchia sladeni (Dall)}

Plate 3: figures 1-4

Hemithyris sladeni Dall, 1910:440, pl. 26: figs. 7-12.

This is a small, smooth rhynchonellid with anterior plication, known from two specimens only taken by the Sealark Expedition, 1905. Lectotype USNM 111086. Cooper (1959:8) made this species the type of Rhytirhychia.

\section{Striarina, new genus \\ l'LATE 2: Figures 26-38}

Small, transversely triangular to pentagonal; inequivalve, the dorsal valve having the greater depth; anterior commissure broadly uniplicate. Beak small, nearly straight, with foramen readily visible; foramen fairly large, hypothyridid; deltidial plates fairly large, disjunct. Surface finely costellate.

Ventral valve interior with strong, triangular teeth supported by strong, flaring dental plates; pedicle collar short. Muscle field slightly thickened, lying anterior to the delthyrial cavity. Individual muscles not resolvable.

Dorsal valve with broad, deep, corrugated sockets bounded by moderately strong socket ridges; outer hinge plates narrow and concave; crural bases moderately elevated and bounding the outer hinge plates. Crura short, of the falcifer type, and with rounded distal extremities. No median septum but a slender median ridge.

TY'P-SPEC1Es.-Rhynchonella valdiviae Helmcke, 1940:290, figures 37-39.

Diagnosis.-Finely costellate rhynchonellid without median septum.

Types.-Holotype: Zoological Museum Berlin 1283. Figured paratypes: USNM 549729a, b.

Locality.-Valdivia station 165, southwest of St. Paul Island at 672 meters.

COMPARISON.-In form and ornamentation this genus is most like Compsothyris but its ornamentation is stronger, the crura are of the flacifer type, whereas those of Compsothyris are of the spinulifer type. Striarina is not provided with a strong median septum like that of Compsothyris. The septum of the latter genus enlarges and thickens with age and creates a secondary septalium-like chamber under the cardinalia. This does not take place in Striarina.

ETrmology.-The generic name Striarina is derived from the Latin "stria," meaning furrow. 


\section{Order Uncertain}

Suborder THECIDEIDINA Elliott, 1958

Superfamily THECIDEACEA Gray, 1840

This suborder and superfamily comprise small cemented forms that are difficult to find. Nevertheless a fair number of them are known. Of modern genera two are found in the Indian Ocean: $L a$ cazella and Thecidellina. The former is best known in modern seas from the Mediterranean, but it is also known from Atlantic waters off Jamaica and the Dominican Republic. Thecidellina is much more widely distributed, as it occurs in the Pacific Ocean as well as in the Atlantic around the West Indies. Both genera are rare in the Indian Ocean. These two genera are commonly found in water less than 200 meters in depth.

\section{Family THECIDELLINIDAE Elliott, 1958}

Genus Thecidellina Thomson, 1915

\section{Thecidellina blochmanni Dall}

Plate 8: Figures 27-30

Thecidellina blochmanni Dall, 1920:283.-Elliott, in Williams, 1965:589, figs. 742, 743.

This species was listed by Helmcke (1939:216) in faunas from the Pacific, but the type specimen is definitely from the Indian Ocean. The type specimen was sent to Dall by Blochmann, who states in a letter dated September 6, 1911, that it came from Christmas Island south of Java at 84 meters.

Thecidellina is common about the West Indies and fairly abundant around a number of islands in the Pacific: Bikini, Guam, and Eniwetok. It is also known as a fossil as early as Eocene in the West Indies and in sediments of the same age in the Pacific (island of Eua).

TYPES.-Holotype: USNM 227822.

Family THECIDEIDAE Gray, 1840

Genus Lacazella Munier-Chalmas, 1881

\section{Lacazella mauritiana Dall}

Plate 1: Figures 7-9

Lacazella mauritiana Dall, 1920:282.

A single specimen from the island of Mauritius bears the catalog number USNM 173593. The genus is very rare in the Indian Ocean, and suggests derivation from the Mediterranean along with Argyrotheca, Dallithyris, and Pantellaria. No depth data given.

\section{Order TEREBRATULIDA Waagen, 1883}

Superfamily TEREBRATULACEA Gray, 1840

Family TEREBRATULIDAE Gray, 1840

Subfamily TEREBRATULINAE Gray, 1840

Genus Gryphus Megerle von Mühlfeldt, 1811

Gryphus africanus, new species

Plate 4: figures 31-38

Small, elongate oval in outline, with the sides broadly rounded and the anterior margin narrowly rounded; posterolateral margins forming an angle of about $74^{\circ}$. Anterior commissure rectimarginate; beak small, erect; foramen mesothyridid; deltidial plates conjunct, forming a completely visible symphytium. Surface smooth; shell substance thin and translucent. Valves unequal in depth, the ventral valve deeper than the dorsal one.

Ventral valve fairly strongly convex in lateral profile; narrowly domed in anterior profile with swollen midregion and short, steep sides; umbonal and median region swollen; anterior slope moderately steep.

Dorsal valve fairly evenly and gently convex in lateral profile; broadly and gently convex in anterior profile with short, steep flanks. Umbonal region narrowly swollen, the swelling extending to the inflated median region; anterior slope gentle.

Ventral interior with strong teeth not strutted by thickening of the subjacent wall; musculature not impressed strongly enough to differentiate its parts. Dorsal valve interior with high, thin, somewhat alate socket ridges and deep sockets; outer hinge plates deeply concave and very narrow; crura long, rounded, supporting a thin rounded loop with concave transverse ribbon, with its rounded apex pointing anteroventrally. Loop in anterior view thin and concave and having the form of Eucalathis.

Measurements in millimeters:

\begin{tabular}{|c|c|c|c|c|c|}
\hline $\begin{array}{l}\text { USNM } \\
\text { specimen }\end{array}$ & Lenglh & $\begin{array}{c}\text { Dorsal } \\
\text { valve } \\
\text { length }\end{array}$ & $\begin{array}{c}\text { Maximum } \\
\text { width }\end{array}$ & Thickness & $\begin{array}{c}\text { Apical } \\
\text { angle }\end{array}$ \\
\hline $550375 a$ & 6.5 & 5.5 & 4.7 & 3.7 & $74^{\circ}$ \\
\hline 550375b & 6.4 & 5.0 & 4.6 & $?$ & $74^{\circ}$ \\
\hline
\end{tabular}


Locality.-Anton Bruun Cruise 7, locality 358A.

Diagnosis.-Small size and conspicuous symphytium with large foramen.

TYPEs.-Holotype: USNM 550375a; figured paratype: USNM 550375b.

COMPARIson.-The nearest species in the Indian Ocean to this one is Gryphus indianensis, new species, which is compared under that species.

This species is assigned to Gryphus because of the similarity of its carclinalia to those of the common Mediterranean genus. The cardinalia of Gryphus have flattish outer hinge plates that are not bounded by a marginal ridge along the edge facing midvalve. This is exactly like the cardinalia of G. africamus and G. indianensis, new species. Although the cardinalia of $G$. africanus are like those of Gryphus, the beak region is not quite the same. The beak is sharper and more elongated than usual in Gryphus. The loop of G. africanus is different Irom that of Gryphus in having the transverse ribbon directed dorsally, but otherwise the loops are essentially the same. The dorsal direction of the transverse ribbon may be retention of a juvenile character in the case of G. africanus.

\section{Gryphus indianensis, new species}

Plate 4: figures 17-30

Small, elongate oval in outline, with rounded sides and maximum width at midvalve; posterolateral margins forming an angle of $60^{\circ}-75^{\circ}$. Anterior margin subtruncate to gently rounded. Valves unequally deep, the ventral valve deeper. Lateral commissure with a sigmoidal curve; anterior commissure rectimarginate to very faintly uniplicate. Beak erect, foramen moderately large, labiate, and permesothyridid; symphytium partly concealed. Color white to yellowish white.

Ventral valve moderately convex in lateral profile, with the most convexity in the umbonal region; anterior profile a low dome with moderately sloping sides. Umbonal region narrowly swollen, the swelling passing into the general convexity at mid. valve. Anterior slope gently convex.

Dorsal valve gently convex in lateral profile, with the maximum convexity just posterior to midvalve; anterior profile moderately strongly domed, appearing more so than the ventral valve; umbonal and median regions moderately swollen; anterior slope moderately steep and gently convex.
Ventral valve interior with small teeth, reinforced by thickening along the valve wall only in old shells; muscle scars not impressed even in old specimens. Dorsal valve interior with small cardinal process in the young, but thick and wide in old specimens; socket ridges strong, outer hinge plates rudimentary. Loop short, descending branch solid and rounded in section; crural processes bluntly pointed, the points almost overhanging the transverse ribbon, which is narrow and without a median fold. Transverse ribbon directed dorsally.

Measurements in millimeters:

\begin{tabular}{|c|c|c|c|c|c|}
\hline $\begin{array}{l}\text { USNMI } \\
\text { specimen }\end{array}$ & Length & $\begin{array}{c}\text { Dorsal } \\
\text { yalve } \\
\text { length }\end{array}$ & $\begin{array}{c}\text { Maximum } \\
\text { width }\end{array}$ & Thickness & $\begin{array}{c}\text { Apical } \\
\text { angle }\end{array}$ \\
\hline $550366 a$ & 11.3 & 9.6 & 8.7 & 6.5 & $72^{\circ}$ \\
\hline $550366 \mathrm{~b}$ & 11.1 & 9.7 & 8.4 & 7.3 & $72^{\circ}$ \\
\hline $550366 c$ & 11.0 & 9.6 & 7.8 & 6.4 & $68^{\circ}$ \\
\hline $550366 \mathrm{~d}$ & 9.8 & 8.5 & 7.0 & 5.6 & $64^{\circ}$ \\
\hline $550366 \mathrm{c}$ & 9.0 & 7.5 & 6.6 & 5.0 & $73^{\circ}$ \\
\hline
\end{tabular}

Locality.-Anton Bruun Cruise 9, stations 445, 465.

Diagnosis.-Small, elongate oval Gryphus, with short loop and narrow transverse band in the loop.

TYPes.-Holotype: USNM 550366a. Figured paratypes: USNM $550366 \mathrm{~b}$, c. Unfigured paratypes: USNM 550366d, e.

COMPARISON.-Gryphus indianensis is much larger than G. africanus, although it is a rather small shell for the genus. The beaks are quite similar, but that of G. indianensis is more incurved. Details of the interior more readily separate the two, because G. indianensis has a fairly large cardinal process, and the inner hinge plates are poorly developed. Moreover, although the loop is directed dorsally, it has a small and very narrow median fold that is clirected ventrally.

In the main part of the Indian Ocean no small terebratuloid is known. Muir-Wood (1959:288) records Dallithyris murrayi and D.? cernica (Crosse) and Liothyrella moselyi (Davidson) and L. winteri Blochmann. Each of these is a very large brachiopod and totally unlike $G$. indianensis externally. Dallithyris, however, has cardinalia similar to those of Gryphus. The nearest species for comparison with $G$. indianensis is $G$. capensis Jackson taken from off Capes St. Francis and St. Blaize in 75-125 fathoms (137-229 meters) at the south end of Africa. Gryphus capensis is an elongate form, narrower than $G$. indianensis, somewhat larger with a 
narrower loop, with more elongated outer hinge plites, nearly parallel sides, and with a very narrow transverse ribbon in the loop which is "arched ventrally" (Jackson, 1952:16). Gryphus capensis is also provided with a thin, dorsal median ridge which is not present in $G$. indianensis and rare in this group of brachiopods.

Davidson (1880:29, pl. 2: figs. 5, 6) describes and figures under the name of Terebratula vitrea minor (not Philippi 1836) two specimens of a small terebratulicl, possibly referable to Gryphus. These specimens are compared with $G$. capensis by Jackson (1952:17), who rejects them from that species because they are broader than his species. Davidson's specimens are considerably larger $(15 \mathrm{~mm}$ long by $13 \mathrm{~mm}$ wide) and much rounder than $G$. indianensis. Although Davidson's figures do not give precise detail, the loop also appears different, not having so broad outer hinge plates as G. indianensis. Davidson's specimens are assigned by Helmcke (1940:258) to his species, Liothyrina agulhasensis. The narrow form of the loop and the flattish outer hinge plates suggest Gryphris rather than Liothyrella $[=$ Liothyrina $]$ as the genus of Helmcke's species.

\section{Family CANCELLOTHYRIDIDAE Thomson, 1926}

\section{Subfamily CANCELLOTHYRIDINAE Thomson, 1926}

\section{Genus Terebratulina D'Orbigny, 1847}

\section{Terebratulina abyssicola (Adams and Reeve)}

Terebratula abyssicola Adams and Reeve, 1850:72, pl. 21: fig. 5.-Reeve, 1860: pl. 4: fig. 14.

$T$ radiala Recve, 1860: pl. 3: figs. 7a-b.

Terebratulina caput-serpentis Lin. septentrionalis Couthouy Davidson, 1880:33.

Terebratulina abyssicola (Adams and Reeve).-Davidson, 1886:37, pl. 5: fig. 54.-Dall, 1920:307.-Jackson, 1952: pl. 11: pl. I: figs. 5-7.-Hclmcke, 1938:239; 1940: (29) 243.

$T$ radiala Recve.-Davidson, 1886:34, pl. 6: figs. 9-14.-Dall, 1873:180.

$T$ africana Turton, 1932:260, pl. 70: fig. 1842.

All of the specimens of this species are fragmentary, none showing any important details of the interior. Several of the fragments have the dark color bands so distinctive of the species. The $\mathrm{An}$ - ton Bruun specimens extend the range of the species far to the north. The depth at which specimens described by Helmcke ranged was from 80 meters to 106 meters, but those collected by the Anton Bruun are from only 42 meters.

Locality.-Cruise 7, station 372B.

\section{Terebratulina meridionalis Jackson}

Plate 3: figures 43-45

Terebratulina meridionalis Jackson, 1952:13, pl. 1: fig. 8.

Specimen small, rather widely oval in outline, with well-rounded sides and somewhat truncated anterior margin; maximum width at midvalve; posterolateral margins forming an angle of $82^{\circ}$. Beak nearly straight, truncated; foramen small for the genus, submesothyridid; deltidial plates small, disjunct. Anterior commissure rectimarginate. Surface costellate, costellae strong on the umbones and lateral shoulders, but becoming weak and unclear on the more anterior parts of the shell.

Ventral valve slightly deeper than the dorsal valve, fairly strongly convex in lateral profile, with maximum convexity posterior to midvalve; anterior profile gently but somewhat narrowly convex with rather long, gently sloping sides. Umbonal and median regions swollen; anterior somewhat flattened.

Dorsal valve gently convex in lateral profile and most convex posteriorly; anterior profile similar to that of the ventral valve, but not quite so deep. Umbonal and median regions swollen, but anterior somewhat flattened.

Interior with a stout loop, having a very broad transverse band and stout, anteriorly pointed descending element. Crura rounded and rather thin.

Measurements in millimeters:

\begin{tabular}{|c|c|c|c|c|c|}
\hline $\begin{array}{l}U S N^{\top} M \\
\text { specimen }\end{array}$ & Length & $\begin{array}{c}\text { Dorsal } \\
\text { valve } \\
\text { length }\end{array}$ & $\begin{array}{c}\text { Maximum } \\
\text { width }\end{array}$ & Thickness & $\begin{array}{c}\text { Apical } \\
\text { angle }\end{array}$ \\
\hline 550367 & 10.2 & 9.9 & 8.2 & 47 & $82^{\circ}$ \\
\hline
\end{tabular}

Diacinosis.-Terebratulina with evanescent costellae.

Trprs.-Figured hypotype: USNM 550367.

Locality.-Anton Brum. Cruise 8, locality 400C.

Discussion.-The identification of this specimen with $T$. meridionalis Jackson is based on the fact that the costellae are evanescent, a point empha- 
sized by Jackson, and that the proportions of the Anton Bruun specimen are almost identical to those of $T$. meridionalis. It is suggested that the specimen here described is a young individual of Jackson's species. If this be true, the range of $T$. meridionalis is extended a considerable distance to the north and east.

\section{Terebratulina species 1}

Plate 3: figures 32-35

Small, oval in outline, with rounded sides and narrowly rounded anterior margin; posterolateral margins forming an angle of $72^{\circ}$. Beak obliquely truncated; foramen large. Surface multicostellate, costellae appearing in four generations, closely crowcled, subangular posteriorly, but flattening and crowding anteriorly, three costellae in $1 \mathrm{~mm}$ at the anterior margin. Posterior costellae beaded, the beads appearing as nodes on the posterior lateral margins and slopes. Anterior commissure gently uniplicate.

Ventral valve moderately convex in lateral profile, but flatly convex in anterior profile; anteromedian half flattened to form an ill-defined sulcus. Dorsal valve with about the same depth as the ventral valve, flatly convex in lateral profile, but with anterior profile similar to that of the opposite valve. Umbonal region moderately swollen, the swelling continuing to the anterior margin to form a low fold.

Dorsal valve interior with high, stout socket ridges, median roughened area serving as a cardinal process and slight ridgelike outer ridges that interlock with the troughs in the ventral teeth. Crura stout, rounded in section; loop very stout with a broad, thick ring, protuberant strongly on its anterodorsal side.

Measurements in millimeters:

\begin{tabular}{|c|c|c|c|c|c|}
\hline $\begin{array}{l}\text { USNM } \\
\text { specimen }\end{array}$ & Length & $\begin{array}{c}\text { Dorsal } \\
\text { valve } \\
\text { length }\end{array}$ & $\begin{array}{c}\text { Maximum } \\
\text { width }\end{array}$ & Thickness & $\begin{array}{c}\text { Apical } \\
\text { angle }\end{array}$ \\
\hline $550370 \mathrm{a}$ & 6.7 & 5.7 & 5.2 & 3.0 & $72^{\circ}$ \\
\hline
\end{tabular}

LOCALITY.-Anton Bruun Cruise 1, station 18A.

Diagnosis.-Small Terebratulina with closely crowded costellae.

TyPEs.-Figured specimens: USNM 550370a, b.

Discussion.-The size of the specimens here dis- cussed suggests that they are immature, but the stout, thick character of the loop and the adult appearance of the ornament indicate a mature specimen. Nevertheless, it has not been possible to identify the species with any established Indian Ocean terebratulinas or any described East Indian species. Inasmuch as the species is represented by so few specimens (about 9 very small individuals), besides the figured ones, it seems best not to name this Terebratulina.

Terebratulina valdiviae Blochmann was taken from 366 fathoms on the west side of Sumatra about 7 degrees north of the above Anton Bruun. locality. Terebratulina species 1 is from shallow water (77 meters) but appears not to be related to Blochmann's species. I have compared closely young stages of $T$. valdiviae with $T$. species 1 , but the former is a very wide and rounded species, so that its outline at a stage comparable to that of the Anton Bruun specimens is much more rounded and the ornament more beaded.

\section{Terebratulina species 2}

Plate 3: figures 5-8

Small, elongate oval in outline, with the maximum width slightly below the midline; anterior margin narrowly rounded; posterolateral extremities forming an angle of $65^{\circ}-70^{\circ}$. Beak straight, foramen large; deltidial plates vestigial. Anterior commissure fairly strongly uniplicate. Surface costellate, costellae narrowly rounded, widening anteriorly, but remaining strong and elevated throughout their length; three costellae to the millimeter at the anterior margin.

Ventral valve moderately convex in lateral profile, with the maximum convexity in the posterior half and the anterior half flattened; anterior profile flatly convex, with the median region slightly sulcate; umbonal and postlateral regions convex; sulcus originating on the umbonal region, widening and deepening anteriorly to become moderately deep.

Dorsal valve of about equal depth to the ventral valve, moderately convex in lateral profile, with the maximum convexity in the posterior half; anterior profile moderately domed. Umbonal region moderately swollen, the swelling extending to the anterior margin to form a broad fold. 
Ventral valve with elongated teeth, having narrow slits between the tooth and shell wall; pedicle collar short and thick. Dorsal valve with strongly elevated socket ridges; cardinal process a roughened surface on the posterior margin; crura short, stout, flattened; loop squat and wide, with the crural process thin and delicate and not quite completing the ring. Anterior band fairly thick.

Measurements in millimeters:

\begin{tabular}{|c|c|c|c|c|c|}
\hline $\begin{array}{l}\text { USNMI } \\
\text { specimen }\end{array}$ & Length & $\begin{array}{c}\text { Dorsal } \\
\text { valve } \\
\text { length }\end{array}$ & $\begin{array}{l}\text { Maximum } \\
\quad \text { width }\end{array}$ & Thickness & $\begin{array}{l}\text { Apical } \\
\text { angle }\end{array}$ \\
\hline $550369 \mathrm{a}$ & 7.2 & 6.6 & 5.5 & 3.2 & $67^{\circ}$ \\
\hline $550369 \mathrm{~b}$ & 6.7 & 5.9 & 5.2 & 2.7 & $67^{\circ}$ \\
\hline
\end{tabular}

Locality.-Anton Bruun Cruise 9, stations 444, 445.

TyPes.-Figured specimens: USNM 550369a, b.

Discussion-Compared with Terebratulina valdiriae Blochmann of the same size as Terebratulina species 2, the former species is a much more rounded shell with strongly rounded sides and front. Terebratulina species 2 is strongly triangular. Terebratulina abyssicola (Adams and Reeve) has a similar outline to that of Terebratulina valdiriae and is quite unlike Terebratulina species 2. The sculpture of Terebratulina species 2 is completely unlike that of Terebratulina meridionalis Jackson, the costellae of which become obsolescent anteriorly.

Terebratulina caputserpentis emarginata $\mathrm{R}$ isso is similar in shape to Terebratulina species 2 , but somewhat more convex in its lateral margins and much more strongly costate in the younger parts, which correspond in size to the Indian Ocean specimen. Inasmuch as these Indian Ocean specimens are clearly young, they are not named.

\section{Subfamily EUCALATHINAE Muir-Wood, 1965}

\section{Genus Eucalathis Fischer and Oehlert, 1890}

\section{Eucalathis fasciculata, new species}

$$
\text { Plate 1: Figures 26-28 }
$$

Very small, elongate oval in outline, with a narrow hinge and expanding anterior; sides divergent to the anterolateral extremities; anterior margin broadly rounded; posterolateral angles obtuse; maximum width in the anterior third; lateral commissure straight; anterior commissure faintly uniplicate. Interarea very narrow; foramen wide, triangular, no trace of deltidial plates. Surface fascicostate, primary costae about 18 , broad and subangular with a median elevation, flanked by one or two subsidiary costae on the anterior and anterolateral margins. Posterior and median portions of shell nearly smooth, but costae showing faintly. Costae faintly beaded where intercepted by growth varices. Posterolateral margin with a lew low, spinelike projections.

Ventral valve gently and unevenly convex in lateral profile, the posterior moderately convex, the median region flattened, and the anterior region sloping gently to the anterior margin; anterior profile forming a broad gently convex dome, with long, gently sloping sides. Umbonal region narrowly convex, the convexity not extending beyond miclvalve; sulcus originating near midvalve, shallow throughout and widening anteriorly; sulcus occupied by two major costae.

Ventral interior with small teeth but other details obscure.

Dorsal valve evenly and gently convex, with the maximum convexity at midvalve; anterior profile a gently convex, well-rounded dome; umbonal region narrowly convex, the convexity emphasized by two small, flattened ears; fold low and inconspicuous, originating near midvalve and continuing the umbonal convexity anteriorly as it widens in that direction; fold defined by three median costae. Flanks somewhat swollen and moderately steep. Dorsal valve interior with stout socket ridges welded to the posterior wall; notothyrial area thickened, its posterior roughened to form a wide cardinal process; crura short, with blunt crural processes. Loop short, bluntly triangular, with descending processes wide and stout, meeting medially in a small angular ribbon. Other details not clearly visible.

Measurements in millimeters:

\begin{tabular}{|c|c|c|c|c|c|}
\hline $\begin{array}{l}\text { USNM } \\
\text { specimen }\end{array}$ & Length & $\begin{array}{c}\text { Dorsal } \\
\text { valve } \\
\text { length }\end{array}$ & $\begin{array}{l}\text { Maximum } \\
\text { width }\end{array}$ & Thickness & $\begin{array}{l}\text { Apical } \\
\text { angle }\end{array}$ \\
\hline 0371 & 2.9 & 2.6 & 2.6 & $\mathrm{I} .1$ & $85^{\circ}$ \\
\hline
\end{tabular}

Logaltir-Anton Bruun Gruise 7, station $363 \mathrm{k}$.

DIACNosis.-Small Eucalathis with shallow median sulcus and low fold and with broadly fascicostate ornament. 
TYPES.-Holotype: USNM 550371.

Comparison.-Eucalathis is rare in the Pacific or Indian Ocean. It is better known from the northern and central areas of the Atlantic, where several species have been named. Two new species, much larger and differently ornamented than the one from the Indian Ocean, have been found in the Antarctic. Eucalathis murrayi Davidson found between Fiji and Kermadec Islands is the one described species from the Pacific. It differs from $E$. sulcala in larger size and stronger and less numerous costae.

The Atlantic species are: E. tuberala (Jeffreys) from off Gibralter, E. ergastica Fischer and Oehlert off $S$ pain, and $E$. trigona (Jeffreys) from off the Portugal Coast. Dall (1920:323) identified E. murrayi from off Havana, Cuba, but it is clearly not this species. Eucalathis tuberata is a small species, but still larger than E. fasciculata. It is not so widely triangular and is more numerously costate than the Indian Ocean species. Another species larger and more closely costate than E. fasciculata is $E$. ergastica. This species does not have the obsolescence of the costae on the umbonal regions as is so conspicuous in the Indian Ocean specimen. Eucalathis trigona is a small, thin-shelled species, more distantly costate than E. fasciculata and having a loop more rounded anteriorly than usual in the genus. Dall (1920:324) questions the generic affinities of E. trigona.

All of the species of Eucalathis so far described come from water having a depth greater than 1000 feet and some are from very deep water. Eucalathis tuberata has been taken from 2738 meters. Eucalathis fasciculata is no exception, as it comes from more than 1280 meters.

\section{Subfamily CHLIDONOPHORINAE Muir-Wood, 1959}

\section{Genus Chlidonophora Dall, 1903}

\section{Chlidonophora chuni Blochmann}

Plate 8: Figurfs 17-26

Tercbratula sp.-Alcock, 1894:139; 1902:283.

Terebralulina Chun, 1900:404, 405, 2 figs.

Chlidonophora chuni Blochmann in Chun, 1903:435, 436, 2 ligs.-Blochmann, 1906:695, 696.-Dall, 1920:323.-Thomson,
1927:182.-Helmcke, 1938:234, figs. 169, 233; 1940:239, fig. 6.-Muir-Wood, 1959:296, pl. 4: figs. 5-7.-Licharew, 1960: 118, fig. 3.-Muir-Wood in Williams, 1965:H810, figs. $686 \mathrm{~g}, h$.

This interesting little brachiopod has been well described by Helmcke (1940:239) and Muir-Wood (1959:296); consequently there is little to add except a description of the loop and cardinalia which have hitherto not been figured. Muir-Wood described the lophophore, but did not figure the cardinalia and loop. One of the most interesting leatures of this species is its pedicle. This has been figured several times (Helmcke 1940:241; and MuirWood, pl. 4). The pedicle is very long and frays distally into long strands that penetrate the shells of Globigerina and other foraminifers of the ooze on which it lives. This contrasts strongly to the pedicle of Chlidonophora incerta (Davidson), the only other known species, the pedicle of which frays immediately on emergence from the foramen, to produce a radiating effect.

The loop of $C$. chuni contrasts strongly to that of $C$. incerta. The former has stout, convergent descending branches and a fairly long, tapering region anterior to the crural processes, which are low and blunt. The band anterior to the crural processes is narrowly pointed, whereas that of $C$. incerta is rounded. The lophophore which is strongly and densely spicular is described by MuirWood as subplectolophus. The numerous spicules account for the fact that the loop when dried maintains its shape and does not shrivel. Muir-Wood's figures $(1959, \mathrm{pl} .4$ : figs. 6, 7) of the lophophore show this to perfection.

The specimens taken by the Anton Bruun extend the range of this species from the Maldive Islands near which it had hitherto been confined to about 20 degrees of latitude to the south and over 30 clegrees of longitude to the west.

Chlidonophora incerta (Davidson) occurs in the Atlantic at or near the equator, in the Carribean region, off the West Indies, and in the Gulf of Mexico. Like its relative in the Indian Ocean it inhabits deep water.

TYPES.-Hypotypes USNM 550439; 550440; paratype USNM 110436a.

Locality.-Anton Bruun Cruise 7, station 363j; Cruise 8, station 399C. 
Subfamily AGULHASIINAE Muir-Wood, 1965

\section{Genus Agulhasia W. King, 1871}

Agulhasia davidsoni W. King

Plate 4: Figures 1-14

Agulhasia davidsoni W. King, 1871:111, p1. 11: figs. 1-7.Thomson, 1927:182.-Helmcke, 1940:242, fig. 7.-Jackson 1952:9.

Terebratulina (Aguthasia) davidsoni W. King.-Davidson, 1886:36, pl. 7: figs. 1-5.

Since it was first described, the shell anatomy of this interesting little brachiopod has not been examined in detail. The Anton Bruun dredged two lots of specimens from the vicinity of Durban, which extencls the range of the species farther to the north and east than hitherto reported. Although specimens are numerous in one of the lots (Anton Brum Cruise 7 , station $391 \mathrm{H}$ ), not one of them was alive when collected and none preserves the loop intact. Most of the specimens are thick shelled and water worn, so that details of the exterior ornament are not well preserved. The thickness of the test on the other hand emphasizes some of the interior characters.

Description of the exterior need not be repeated as this has been adequately described. The most interesting features of the genus are elongation and consequent complication of the beak and the loop, which seem to have been inaccurately described and figured. These characters separate the genus at once from Terebratulina, which was at one time thought to be its adult expression.

The beak is greatly elongated and attenuated. The deltidial plates margin each side of the delthyrium and are so broad and convex as mistakenly to suggest that they are the interareas of a palintrope (Jackson, 1952:10). Between the deltidial plates and extending from the apex almost to the umbo of the dorsal valve is an apical plate, called a pedicle collar by Thomson (1927:182). This evidently grew pari passu with the development of the elongated beak, and restricted the pedicle opening. It also formed a pedicle tube or groove for a probable long, thin pedicle. This plate does not seem to be the same sort of pedicle collar that occurs in many terebratulids. It is akin to the apical plate seen in Cryptopora (see before) and in Hemithiris (Cooper, 1959:46, pl. 3: fig. 16). It restricts the hypothyridid foramen to a small opening for a thin pedicle.
The dorsal valve of Agulhasia is like that of Terebratulina except for the cardinal process, which is narrow and has a long shaft and lobate myophore. The carclinalia are not buttressed by a stout median septum as stated by Thomson (1927: 182). The supposed septum is the shaft of the cardinal process, which does not extend anterior to the notothyrial cavity. The myophore consists of a thick median lobe with median crest and two thin lateral lobes separated by narrow, slitlike depressions, which are the places of insertion of some of the muscles, probably the diductors. The socket riclges are very thick and are built up as walls parallel to the shaft of the cardinal process. In very old shells a thickening runs for a short distance anterior to the socket ridge just under the crural base. The crura are short and the loop very slender and delicate for an otherwise rather obese shell. The crural processes are short, sharply pointed, and slencler. The slim descending branches of the loop converge anterodorsally and are united in a slencler transverse loop, the point of which is directed ventrally. The loop is thus quite like that of Chlidonophora or Eucalathis, except that the loop of the latter two is generally more triangular anteriorly. The loop of Agulhasia is more elongate oval than triangular. The loop does not flare laterally, with a medially folded transverse ribbon, as given in King's drawing which has been repeated in many publications (Muir-Wood in Williams, 1965:H812; Thomson 1927:183).

Agulhasia is mostly a shallow-water brachiopod. Davidson (1886:36) reports it from 45-60 fathoms from the Agulhas Bank, South Africa. The National Museum has specimens from the same place and depth (USNM 549456). The Anton Bruun material from Cruise 7, Station 358A, at 366 meters, Durban Bay, is an exception. The specimens from this locality are all dead shells and may not have lived at this greater depth. Specimens from Stations $391 \mathrm{~J}$, at 57 meters, are in much shallower water than the above occurrences.

TYPFs.-Figured hypotypes: USNM 549456, 550408 a-d.

\section{Superfamily TEREBRATELLACEA W. King, 1850}

\section{Family THAUMATOSIIDAE, new family}

Terebratellacea with amphithyrid foramen and 
schizolophus lophophore but no loop, septum, or other calcareous support.

\section{Thaumatosia, new genus}

Minute to small, quadrate to subcircular in outline; hinge wide; anterior commissure rectimarginate to broadly and slightly sulcate; foramen large, amphithyridid; interareas fairly broad; ornament consisting of broad, poorly defined costae; color yellowish to pinkish white, with salmon to crimson stripes marking the costae. Shell substance coarsely punctate.

Ventral valve interior with small, curved, hooklike teeth without supports, underlying the small palintropes; pedicle attachment occupying the apex and marked by a median groove; median septum low, extending to beyond midvalve; adductor scars small, located between proximal end of septum and callosity; cliductors flabellate, inserted in median groove at apex.

Dorsal valve interior without loop or other brachial supports; sockets broad and deep, formed by broad fulcral plates; socket ridges erect, short, and thick and buttressed by short, thick supporting plates, continued anteriorly as low ridges for a short distance.

Trpe-specifs.-Thaumatosia anomala, new species.

Diagnosis.-Small punctate Orthis-like shells without any calcified lophophore support.

Comparison.-The form and articulation of this genus are reminiscent of some of the Orthacea. The nearest modern relatives appear to be Ampithyris and Platidia, which have an amphithyridid foramen. Thaumatosia differs from Amphithyris in its outer form, costation, ventral median septum and character of the articulation. Amphithyris is not provided with the tooth and socket arrangement characteristic of Thaumatosia. The latter does not have a median septum in the dorsal valve like that of Amphithyris. Platidia resembles Amphithyris more closely than it does Thaumatosia because it is not costate but internally it is unlike either genus. The dorsal valve of Platidia has a small loop and is thus completely unlike that of Thaumatosia.

Gwynia is a minute and little known brachiopod which suggests relationship to Thaumatosia but it is not amphithyrid and some specimens show a loop condition signifying relationship to Argyrotheca.
ETYMOLOGY.-The generic name Thaumatosia: is derived from the Greek word "thaumatos," meaning a marvel.

\section{Thaumatosia anomala, new species}

Plate 5: rigures 20-37; Plate 8: figure 31

Minute to small, quadrate to subcircular in outline, with a straight hinge not quite equal in width to the maximum valve width that is near midvalve; sicles gently rounded; anterior margin variable, truncated in the young but slightly to moderately emarginate in the adult. Interarea short, orthocline to faintly anacline. Surface marked by broad, low costae numbering about 12 in the adult. Costae variable, indistinct in some young and old shells. Color banding ranging from salmon to crimson, the bands corresponding to the costae.

Ventral valve gently convex in lateral profile, with the maximum curvature near midvalve; anterior profile a broad, low dome with flattened and gently sloping sides. Beak broad and ill defined. Anterior half to third forming a broad sulcus or flattened area.

Dorsal valve gently convex in lateral profile and broadly but flatly convex in anterior profile; anterior half with a broad sulcus, deeper than that of the pedicle valve and forming the anterior emargination of some specimens. Pedicle opening large, triangular; umbonal region somewhat narrowly swollen but losing the swelling in the sulcus. Flanks flatly convex.

Interior as defined for the genus.

Measurements in millimeters:

\begin{tabular}{|c|c|c|c|c|c|}
\hline $\begin{array}{l}\text { USNM } \\
\text { specimen }\end{array}$ & Length & $\begin{array}{l}\text { Dorsal } \\
\text { valve } \\
\text { length }\end{array}$ & $\begin{array}{l}\text { Hinge } \\
\text { width }\end{array}$ & $\begin{array}{l}\text { Maximum } \\
\text { width }\end{array}$ & Thickness \\
\hline $550347 a$ & 2.6 & 2.1 & 2.6 & 3.3 & 1.5 \\
\hline $550347 \mathrm{~b}$ & 2.1 & 1.5 & 1.8 & 2.4 & 0.9 \\
\hline $550347 c$ & 2.0 & 1.9 & 2.1 & 2.5 & 0.8 \\
\hline
\end{tabular}

Diagnosis.-Small costate Thaumatosia.

TYPES.-Holotype: USNM 550347c. Figured paratypes; USNM 550347a, b, d-f; 550376.

Locality.-Anton Bruun Cruise 1, stations 18A, 29.

COMPARISON.-This is the only known species of this genus. The radial costation of Thaumatosia separates it from smooth or capillate Platidia and smooth Amphithyris. 
Suborder TEREBRATELLINIDAE Muir-Wood, 1955

\section{Superfamily TEREBRATELLACEA W. King, 1850}

Family MEGATHYRIDIDAE Dall, 1870

Genus Argyrotheca Dall, 1900

Argyrotheca somaliensis, new species

Plate 5: figures 1-19

Small, grayish yellow in color, hemipyramidal in profile, and transversely subrectangular in outline. Hinge less than, equal to, or forming the widest part. Sides gently rounded and anterior broadly rounded, with the anterior margin strongly to moderately scalloped. Anterior commissure with a slight wave toward the ventral valve; foramen large, fairly regular with deltidial plates absent or rudimentary. Surface costate, costae thick and rounded, appearing in three generations with six primary costae at the beak of the ventral valve. First intercalation appearing near the beak $(1 \mathrm{~mm})$, but the second intercalated generation appearing near the anterior margin. Costae numbering 11 on the pedicle valve.

Ventral valve hemipyramidal in lateral profile, but moderately convex in anterior profile and forming a broad, blunt $\vee$. Fold indistinct, formed by the median three costae; flanks moderately steep. Interarea strongly apsacline.

Dorsal valve flatly convex in anterior and lateral profiles; sulcus narrow and shallow, occupied by a median costa of the first intercalated generation for about half its length. Flanks gently swollen; posterolateral extremities flattened. Primary costae four.

Ventral interior with long, narrow teeth; apical plate small and posteriorly confined; median septum slender, low and extending from apical plate nearly to the anterior margin. Dorsal valve with a small, roughened cardinal process at the apex; notothyrial region thickened and forming a broad trough leading to the median septum; crura broad and flat, stout; crural process horizontal, long and pointed; loop a slender ribbon free of the valve floor only at the posterolateral portion and the part immediately adjacent to the septum. Medium septum thick, rising to a crest at about one-third the length from the anterior margin; anterior slope of septum steep and marked by three serrations.

Measurements in millimeters:

\begin{tabular}{|c|c|c|c|c|c|}
\hline $\begin{array}{l}\text { USNM } \\
\text { specimens }\end{array}$ & Length & $\begin{array}{c}\text { Dorsal } \\
\text { valve } \\
\text { length }\end{array}$ & $\begin{array}{l}\text { Hinge } \\
\text { width }\end{array}$ & $\begin{array}{l}\text { Mid- } \\
\text { width }\end{array}$ & Thickness \\
\hline 550344 & 3.9 & 3.0 & 3.1 & 3.0 & $?$ \\
\hline $550345 a$ & 4.0 & 3.0 & 3.8 & 4.5 & 2.3 \\
\hline $550346 a$ & 3.5 & 2.9 & 4.0 & 4.0 & 2.1 \\
\hline
\end{tabular}

Localities.-An.ton Bruun Cruise 9, station 444, 445 , and 447.

Diagnosis.-Small coarsely costate Argyrotheca, rectangular in outline with well-formed delthyrium ancl scalloped anterior margin.

Tripes.-Holotype: USNM 550346a. Figured paratypes: USNM 550344, 550345a, 550372. Unfigured piratypes: USNM 550345b, $550346 \mathrm{~b}$.

Comparison.-Of Mediterranean species this one is most like Aigyrotheca cordata (Risso), but numerous differences are at once apparent. The Mediterranean species is generally a smaller one than that from the Inclian Ocean and the costation is stronger, the costae being strong, broad, and only gently swollen and forming a strongly scalloped anterior. The scalloping is much broader and the individual lobes less numerous than those of $A r g y$ rothera somaliensis. Furthermore the Mediterranean spccies is often rose colored, especially at the anterior part, while $A$. somaliensis is pale yellow.

All of the Caribbean species are larger, differently ornamented or gaily colored and thus in strong contrast to $A$. somaliensis. One Caribbean species, A. schrammi (Crosse), is similar in size but is generally red, wide-hinged with angular lateral extremities, large apical plate, a short, high median septum in the ventral valve, and a more strongly crested and more numerously serrated median septum in the clorsal valve.

The Mediterranean and Caribbean are the two regions in which Argyrotheca is most abundant. The genus is not well known in the Pacific but has been taken from the waters of Australia: A. australis (Blochmann); and off Tasmania: $A$. mayi (Blochmann). Argyrotheca in a diminutive form is found around Bikini and Eniwetok. Argyrotheca somaliensis is completely different from both of the austral species and those from Bikini and Eniwetok, as it is mucl larger and strongly costate. Argyrotheca lowei Hertlein and Grant, from the 
Gulf of California, is another Pacific species. It is about the same size as $A$. somaliensis, but has broader and less costae, a wider and very irregular delthyrium, a different loop, and the median septum of the ventral valve is shorter.

\section{Argyrotheca jacksoni, new species}

Plate 3: figures 9-13

Small, pentagonal in outline, length and width nearly equal; sides nearly straight; anterior margin slightly concave medially; anterolateral angles narrowly rounded; beak elongated; interareas well developed; apical angle $93^{\circ}$, deltidial plates narrow, margining the delthyrial edge; surface costate, costae numbering five on a side, with an obscure median one. Anterior margin scalloped; punctae coarse.

Ventral valve moderately convex in lateral profile and broadly and moderately convex in anterior profile; most convex in the umbonal region. Sulcus shallow and narrow, extending from the beak to the anterior margin; flanks moderately convex, but with steep slopes to the posterolateral extremities.

Dorsal valve flatly convex in lateral profile, broadly and flatly convex in anterior profile, with the median region slightly carinate and with long, gentle lateral slopes. Median sulcus originating anterior to the umbo, shallow, widening anteriorly to occupy about one-fourth the valve width. Median costa occupying sulcus low and obscure. Median septum present; lophophore schizolophous.

Measurements in millimeters:

\begin{tabular}{lccccc} 
USNM & \multicolumn{3}{c}{$\begin{array}{c}\text { Dorsal } \\
\text { valve }\end{array}$} & & Hinge \\
specimen & Length & length & Width & width & Thickness \\
550432 & 3.3 & 2.9 & 4.5 & 4.4 & 2.2
\end{tabular}

Locality.-Red Sea, reef Ras Muhammad, southernmost Sinai Peninsula.

Diagnosis.-Small yellow-gray Argyrotheca, with rectangular dorsal valves with about 11 costae.

TYPES.-Holotype: USNM 550432.

Comparison.-This species does not compare favorably with any of those described from the Mediterranean. It is more strongly costate than $A$. cistellula (Searles Wood) and less emarginate anteriorly. It is most like $A$. cuneata (Risso) in size, but its ornament is more subdued, its beak more elon- gated, and with narrower interareas on each side of the delthyrium; the anterior margin is not conspicuously scalloped like that of $A$. cuneata, and finally it does not have the delicate pink or red wash between the costae as in $A$. cuneata. It is unlike any of the argyrothecas described from the West Indian region, where members of the genus are plentiful. Finally it is entirely unlike the Argyrotheca somaliensis from the Indian Ocean described herein. That species is much larger and is much more coarsely sculptured than the Red Sea form.

The species is named for Dr. Jeremy Jackson, who presented the specimens.

\section{Family KRAUSSINIDAE Dall, 1870}

\section{Genus Kraussina Davidson, 1859}

\section{Kraussina gardineri Dall}

\author{
Plate 3: figures 36-42
}

Kraussina gardineri Dall, 1910:440, pl. 26: figs. 3-6.

Large for the genus, outline roundly elliptical to crudely rhombic; widest at midvalve; sides somewhat narrowly rounded; anterior very narrowly rouncled; posterolateral margins forming an angle of $98^{\circ}$. Valves unequally deep, the ventral valve having the greater depth; beak broad and truncated; foramen large, semicircular; hinge wide, but narrower than the maximum valve width; interareas very narrow; deltidial plates lacking. Anterior commissure slightly uniplicate. Surface multicostate, costae narrowly rounded to subangular, numbering on the ventral valve 18 at the posterior margin, 35 to 40 at the anterior margin, but very unclear at the posterolateral extremities; costae increasing by bifurcation and intercalation in three or four generations and forming fascicles at the margin. Growth varices about eight in number with four concentrated at the anterior margin.

Ventral valve moderately convex in lateral profile and moderately domed in anterior profile, being somewhat narrowly convex medially but with flattened, fairly steeply sloping sides. Umbonal region swollen, the swelling continuing anteriorly to the front margin to form a narrow but poorly defined fold. Flanks gently convex and with steep slopes. 
Dorsal valve gently convex with the maximum curvature near midvalve and the anterior part flattened; anterior profile broadly and gently convex, with a slight median sulcation. Umbonal region flatly convex; median region slightly swollen; sulcus originating anterior to midvalve, shallow and poorly defined, but producing a slight nasutiform. Flanks gently convex, posterolateral extremities flattened.

Ventral valve interior with small teeth, not buttressed by thickening on the shell wall. Pedicle collar short. Dorsal valve interior with thick socket ridges and broad, open hinge trough containing impressions of the muscles; cardinal process broad; median ridge low, not extending to the hinge trough; brachidium consisting of a Y-shaped process, with a thin proximal blade bearing an expanded plate directed anteriorly.

Measurements in millimeters:

\begin{tabular}{|c|c|c|c|c|c|}
\hline $\begin{array}{l}\text { USNM } \\
\text { specimen }\end{array}$ & Length & $\begin{array}{c}\text { Dorsal } \\
\text { talve } \\
\text { length }\end{array}$ & $\begin{array}{l}\text { Maximum } \\
\text { width }\end{array}$ & Thickness & $\begin{array}{c}\text { Apical } \\
\text { angle }\end{array}$ \\
\hline 111085 & 23.9 & 21.8 & 23.0 & 12.3 & $98^{\circ}$ \\
\hline
\end{tabular}
[=280-225 meters] south of Saya de Malha Banks, Indian Ocean.

DiAgnosis.-Large grayish multicostate Kraussina.

TyPES.-Holotype: USNM 111085.

Comparison.-As pointed out by Dall, this species differs from Kraussina rubra (Pallas) in its dull gray color, in different sculpture, and in the brachial apophyses, which are more slender and delicate than those of $K$. rubra. Dall's figure (1910: pl. 26. fig. 3) of the interior of $K$. gardineri suggests a somewhat old shell obesely thickened. The drawing is misleading when compared with the photographic illustration. Kraussina usually occurs in water less than 200 meters deep, but $K$. gardineri is an exception.

\section{Kraussina species}

pllate 1: Figures 14-17

Very small, pedicle valve measuring $4 \mathrm{~mm}$ long by $3 \mathrm{~mm}$ wide and oval in outline. Sides broadly rounded but anterior narrowly rounded. Anterior commissure rectimarginate. Foramen corresponding to delthyrium, margined by rudimentary deltidial plates. Surface partially costellate, the costellae strongest on the flanks, but indistinct on midvalve from umbo to anterior margin.

Ventral valve gently convex in both profiles. Dorsal valve gently convex, less so than the ventral valve, and with the anterior half flattened to form an ill-defined sulcus.

Ventral valve interior with small teeth, but a broad and long pedicle collar which is anteriorly excavated. Dorsal valve with small socket ridges and a wide, unthickened hinge trough, median septum not extending to the hinge trough, low and bearing two plates forming a $Y$ with the septum. Anterior end of septum bearing a small conical node, a second node appearing anterior to the median septum.

Locality.-Anton Bruun station 358A.

TYPES.-Figured specimen: USNM 550377.

Discussion.-The cardinalia of this little specimen are most like those of Kraussina rather than Mergerlina in not having the median septum meeting the hinge trough and in the form of the brachidium. This structure in this specimen is probably a remnant in a worn specimen because of the shortness of the prongs of the $Y$ and the lack of any points. The specimen is somewhat suggestive of the young of K. rubra (Pallas) in its subdued ornament, but the interior is not well enough preserved for a good comparison.

\section{Genus Megerlia W. King, 1850}

\section{Megerlia echinata (Fischer and Oehlert)}

Plate: 1: figures 1-3; Plate 3: figures 27-31

Mïhlfeldtia echinala Fischer and Oehlert, 1890:73; 1891:90, pl. 7: figs. $13 a-g$.

?Morrisia giganlea Deshayes, 1863:37, pl. 5: figs. 9-11.

Panlellaria echinala (Fischer and Oehlert),-Dall, 1920:336.Jackson 1921:48.

Megerlia cchinata (Fischer and Ochlert).-Atkins, 1961:89-94.

Although not strictly from the Indian Ocean the specimen figured on Plate 1 herein occurs southwest of the Cape of Good Hope. Morrisia Deshayes [= Megerlia echinata (Fischer and Oehlert)], was reported from Reunion Island in the Indian Ocean. This is another Mediterranean and Atlantic type found in the Indian Ocean. As presently identified this species enjoys an ususually wide range. It is known from off Cape Bojador, West Africa, off the Barbados, off Sand Key, Florida, and off New South Wales, Australia. 
Dall (1920:336) refers the Morrisia gigantea Deshayes to Pantellaria echinata but Jackson (1921: 48) believes that it belongs to his new variety of Muehlfeldtia (= Megerlia) truncata paucistriata found in the Persian Gulf. The specimen referred by Dall to Pantellaria echinata, which comes from New South Wales, is a more strongly ornamented shell than the specimen from off the Cape of Good Hope. Atkins (1961) gives convincing arguments for the assignment of Dall's Pantellaria to Megerlia because of similarity of shell form and pedicle opening to those of Megerlia.

Specimens referred to this species from the Red Sea were presented by Dr. Jeremy Jackson. They appear to be young, as indicated by the incompletely developed loop of one of them. This has no ring and the descending branches have not yet developed. Both specimens are distorted from an inhospitable growth position. One of them is developed laterally while the other is greatly elongated. The former specimen exhibits obscure radial costellae, but the other has its ventral valve completely covered by encrusting algae, and the opposite valve gives no indication of radial ornament.

Measurements in millimeters:

$\begin{array}{cccc}\text { USNM } & & & \\ \text { specimens } & \text { Length } & \text { Width } & \text { Thickness } \\ 550431 \mathrm{a} & 3.8 & 5.5 & 2.5 \\ 550431 \mathrm{~b} & 5.4 & 3.8 & 2.9\end{array}$

Locality.-The specimens were taken from the Reef Ras Muhammad, southernmost Sinai Peninsula, Red Sea, a piece of coral from the roof of a cave in the reef. They were associated with Argyrotheca jacksoni, new species.

The Red Sea specimen is referred to Mergerlia echinata because of its strong, linearly arranged granules on the exterior, the distorted form, and the large foramina in both valves.

TYPEs.-Figured hypotypes: USNM 173834 , 550431 .

\section{Genus Megerlina Deslongchamps, 1884}

\section{Megerlina species}

Plate 8: Figure 11

A single but broken specimen is referred to this genus. The ventral valve is nearly complete and measures $7 \mathrm{~mm}$ in length and $8 \mathrm{~mm}$ wide. The surface is faintly and distantly costellate. The foramen is large and distorted, and bounded laterally by narrow interarea. The deltidial plates are vestigial. The teeth are small, and the pedicle collar is broad and slightly elevated anteriorly. Radial rows of low, rounded nodes mark the anterior third of the ventral interior.

The dorsal valve is badly broken, but the cardinalia and a part of the brachidium remain. The socket riclges are thick and bear a small triangular projection near their distal extremity. This interlocks with the trough behind the tooth. The outer hinge plates are concave, thick, and unite with the median ridge, which is thick and extends to about midvalve. The outer hinge plates are excavated anteriorly. The brachidium consists of two thick, inclined plates forming a $V$ on the anterior extremity of the median ridge. Attached on the side of each branch of the $V$ is a short ribbon extending posteriorly and bearing an inward facing hook at its distal end. The hook is now broken from the specimen, but was visible before the crushed flesh was cleaned away.

Locality.-Anton Bruun Cruise 7, station 371E.

Tries.-Described specimen: USNM 550378.

Discussion.-This specimen was compared with an example of $M$. natalensis (Krauss) (USNM 64336) from South Africa (detailed locality not known). The two specimens agree in ornamentation, but the identified specimen is more strongly sulcate. The beak characters agree, but details of the interior vary considerably. The identified specimen has a much more highly developed brachidium than the Anton Bruun specimen, the prongs of the $\checkmark$ being long and the lateral projections extending from their sides much shorter and directed posteromedially. The difference of the interiors makes it impossible to identify these as the same species. Jackson (1952:30-33) places $M$. natalensis (Krauss) in the synonymy of $M$. pisum (Lamarck) on the grounds of external similarity, but confesses that the interior of $M$. pisum is not known and might be different from that of $M$. natalensis. Inasmuch as this information is lacking, it is impossible to tell the relationship of the Anton Bruun specimen to $M$. pisum. 
Family DALLINIDAE Beecher, 1893

\section{Subfamily NIPPONITHYRIDINAE Hatai, 1938}

\section{Nipponithyris Yabe and Hatai, 1934}

Plate 3: figures 14-20

Nipponithyris Yabe and Hatai, 1934:588.-Hatai, 1940:334; in Williams, et al., 1965:H842.

Small, rounded pentagonal in outline; valves unequal in depth, pedicle valve deeper than the clorsal valve; anterior commissure varying from slightly sulcate to fairly strongly sulcate; beak elongated, suberect to erect; foramen small, mesothyridid; deltidial plates conjunct, large, and thick. Surface smooth, except for concentric growth increments. Densely and minutely punctate.

Ventral valve with thick teeth but no dental plates, the delthyrial cavity often thickened by adventitious shell; muscles partly lodged in the delthyrial cavity, partially anterior to it; vascula media strong posteriorly.

Dorsal valve with ponderous and thick socket ridges and deep, wide sockets. Cardinal process small, semielliptical to triangular, confined to the apex. Outer hinge plates obscured by adventitious tissue; crural bases narrow; inner hinge plates forming a $V$-shaped chamber united with the median septum; loop in late campagiform to early terebrataliiform stage, with slender descending branches and thickened hood. Median septum thick, and elevated to point of attachment with crosspieces of loop, low to almost obsolete anteriorly. Muscle scars moderately strongly impressed.

TYPE.-Nipponithyris nipponensis Yabe and Hatai, 1934:588.

Diagnosis.-Small sulcate brachiopods with elongate beak, loop in early to medial terebrataliiform stage.

Comparison.-Externally Nipponithyris suggests Magadina or Frenulina but the loops of both of these are quite different. The loop of Magadina is in an earlier developmental stage compared to Nip. ponithyris and has an incomplete ring. Frenulina on the other hand in its final or frenuliniform stage has the hood so resorbed as to produce a window in the ascending elements, which is a trend toward the Laqueus loop (see below). In Nipponithyris the campagiform loop is resorbed anteriorly along the junction of the ascending and descending branches, thus trending toward the terebrataliiform loop stage which is its adult aspect.

Nipponithyris off the coasts of Japan has a fairly broad toleration of depth as it is found in waters ranging from 86 meters to 454 meters (Hatai, 1940:336, 337).

\section{Nipponithyris afra, new species}

Plate 7: Figures 1-21

Snall; outline pentagonal; biconvex, sides rounded; anterior margin truncated; shell thick and solid; posterolateral margins forming an angle of $90^{\circ}$ to $100^{\circ}$. Anterolateral extremities narrowly rounded; lateral commissure straight; anterior commissure strongly sulcate. Beak erect; foramen small, mesothyridid; deltidial plates large, conjunct, exposed. Surface smooth; periostracum pale yellowish brown; shell white.

Ventral valve unevenly convex, the maximum convexity in the umbonal region; anterior profile moderately domed and with gently sloping sides; umbonal region somewhat narrowly swollen, the swelling extending to the anterior margin and forming a poorly defined fold; lateral slopes gently flattened.

Dorsal valve evenly and gently convex in lateral profile; anterior profile broadly and flatly domed, with the median region slightly depressed and the sides sloping gently. Umbonal region gently swollen; sulcus originating on the umbonal region, widening and deepening anteriorly but never very deep; sulcus at anterior shallow, but forming a short, broad tongue. Flanks gently swollen.

Ventral valve interior with thick teeth buttressed by a thickening that restricts the delthyrial cavity; muscle field deeply impressed; diductors long and narrow; pallial marks moderately impressed, primary trunk leading from the diductor scars strong; lateral trunk weak.

Dorsal valve with cardinalia so thickened that differentiation of plates is difficult; hinge trough very narrow and occupied posteriorly by a long, narrow cardinal process; socket ridges thick; crural bases buried; crura short, with small, pointed crural processes; loop campagiform; descending branches slender, but broadening anteriorly to support a thick rounded hood, with a posterior-facing reentrant on the transverse band. Attachments of 
the loop to the septum short, converging posteriorly; septum rising to a crest at midvalve, where the loop is attached but descending anteriorly to extend almost to the anterior margin; posterior segment of loop stout, high. Pallial trunks fairly strongly impressed.

Measurements in millimeters:

\begin{tabular}{|c|c|c|c|c|c|}
\hline $\begin{array}{l}\text { USNM } \\
\text { specimens }\end{array}$ & Length & $\begin{array}{c}\text { Dorsal } \\
\text { valve } \\
\text { length }\end{array}$ & $\begin{array}{l}\text { Maximum } \\
\text { width }\end{array}$ & Thickness & $\begin{array}{c}\text { Apical } \\
\text { angle }\end{array}$ \\
\hline $550342 a$ & 10.7 & 9.4 & 10.0 & 5.7 & $93^{\circ}$ \\
\hline $550342 b$ & 10.6 & 9.0 & 9.6 & 5.5 & $93^{\circ}$ \\
\hline $50343 a$ & 12.0 & 10.3 & 11.4 & 6.2 & $99^{\circ}$ \\
\hline $550343 b$ & 11.6 & 10.2 & 10.7 & 5.5 & $99^{\circ}$ \\
\hline
\end{tabular}

Locality.-Anton Bruun Cruise 8, stations 398B and 399B.

Diagnosis.-Small pentagonal Nipponithyris, with lairly strong anterior sulcation.

TYPls.-Holotype: USNM 550343a. Figured paratypes: USNM 550342a-d, 550343b, c. Unfigured paratypes: 5500342,550343 .

Comparison.-The nearest relative of this species occurs in Japanese waters. Nipponithyris afra differs lrom $N$. nipponensis Yabe and Hatai in being rouncler in the adult form, in having a more strongly sulcate anterior commissure and a more compact loop, with stouter adult attachments of the loop to the septum.

\section{Family LAQUEIDAE Thomson, 1927*}

\section{Subfamily FRENULININAE Hatai, 1938}

Following the lead of Thomson (1927:242), Firmulina and its related genera as described below are placed in the Laquaeidae because of the laquaeilorm development of their loops. In a discussion of "Kingena" alcocki Joubin, Thomson showed that the loop figured by Joubin was of Laqeues type, but he hesitated to transfer the species to Laqueus because of its disjunct deltidial plates. He states, "Il it proves to belong to the Frenulina stock, representing a more advanced loop stage in that stock, then it will be necessary to transfer Frenulina to the Laqueinae, since its further development of loop is to the Laqueus and not to the Terebratalia type."

Frenulina cruenta and Compsoria suffusa as well

*Translated name, from Thomson (1927:256). as "Kingena" alcocki have a laquaeiform loop and are clearly related to Frenulina, representing an advanced condition of the latter genus. Actually the largest specimens of Frenulina sanguinolenta (Gmelin) in the national collection have a loop in about the same stage of development as specimens of Compsoria. Furthermore, the condition of the deltidial plates in Frenulina sanguinolenta is variable, some specimens having conjunct deltidial plates (USNM 337580), but others with the plates (lisjunct. This is also true of specimens of Compsoria. Consequently, the condition of the deltidial plates offers no hindrance to the transfer of Frenulina and allies from the Dallinidae to the Laqueidae.

The form of the loop of Frenulina usually called the frenuliniform stage is actually not the final stage of the loop of Frenulina. Large specimens of Frenulina have the loop in the condition of that of $F$ cruenta, in which the descending branches are attached to the septum by rather long lamellae and the clescending and ascending branches are attached by a fairly thin ribbon. In the loop usually figured as the frenuliniform stage there are no transverse attachments of the loop to the septum, the ascending branches being approximate and attached directly to the loop. This stage might rather be called preterebrataliiform stage than frenuliniform, which would eliminate any confusion caused by using a member with laqueiform loop tendencies. In other words the so-called frenuliniform stage in the development of the dallinid loop should be dropped from the sequence which then would be: precampagiform, early campagiform, campagiform, early terebrataliiform, terebrataliiform, early dalliniform, and finally dalliniform.

\section{Genus Frenulina Dall, 1894}

\section{Frenulina sanguinolenta (Gmelin)*}

Plate 6: ilgures 1-3; plate 8: figures 12-16

Figures of Frenulina sanguinolenta (Gmelin) have been introduced for comparison with the loop of Compsoria and the color pattern of Frenulina crucnta Cooper. A growth series of the Frenulina is figured to show that the frenulina stage could

* For complcte synonymy, see Davidson, 1886-1888:108 (un(ler Megerlen sunguinea) and Hatai (1940:327). 
not have produced the terebratliiform loop which is supposed to follow. The laquaeiform character of the loops of Compsoria and Frenulina become clear.

TyPEs.-Figured specimens: USNM 292546a, b, d, f and g; 337539a; 342205.

\section{Frenulina cruenta, new species}

Plate 6: figures 4-45

Small to mediunt, longitudinally subelliptical in outline, with rounded sides; maximum width at midvalve; posterolateral margins forming an angle of $75^{\circ}-82^{\circ}$; anterior margin somewhat narrowly rounded. Lateral commissure straight; anterior commissure rectimarginate. Beak truncated, erect to slightly incurved; foramen large, slightly labiate, mesothyridicl; deltidial plates small, conjunct in the adult. Surface smooth; color bands consisting of a median and two lateral bands of elongate, red dashes or cuneiform-like markings, those of the median band tending to become solid red at the anterior.

Ventral valve greater in depth than dorsal valve, moderately convex in lateral profile with maximum convexity near midvalve; anterior profile somewhat narrowly domed and with steeply sloping sides. Beak short, umbonal region narrowly convex, convexity continuing to midvalve; anterior slope somewhat flattened.

Dorsal valve gently and moderately convex in lateral profile, broadly and moderately convex in lateral profile with moderately sloping flanks. Median region swollen; anterior slope moderately steep. Umbonal region slightly swollen and underlying the deltidium of the opposite valve.

Ventral valve interior with small, thick teeth buttressed by short, thick, receding dental plates separated from the valve wall by moderately deep cavities. Floor of delthyrial cavity thickened. Muscle field anterior to delthyrial cavity, deeply impressed in old shells; diductor scars elongate.

Dorsal valve interior with strong socket ridges and deep sockets; outer hinge plates narrow; crural bases narrow; inner hinge plates not developed or vestigial in adults. Septum thin, elevated, strong, joining two recumbent plates at the posterior that unite with and buttress the crural base, well marked in the young but somewhat obscured in old adults, but usually defined by more or less distinct cavitiës. Cardinal process small, transverse. Adult loop in an advanced frenuliform condition: the descending and ascending lamellae thin and delicate; the ascencling lamellae uniting with a moderately broad hood which is attached to the junction of the descending branches with lateral attachments to the septum by moderately broad lamellae. Crura short, crural processes bluntly pointed.

Measurement in millimeters:

\begin{tabular}{|c|c|c|c|c|c|}
\hline $\begin{array}{l}\text { USAM } \\
\text { specimens }\end{array}$ & Lenglh & $\begin{array}{c}\text { Dorsal } \\
\text { talve } \\
\text { length }\end{array}$ & $\begin{array}{l}\text { Maximum } \\
\text { width }\end{array}$ & Thickness & $\begin{array}{c}\text { Apical } \\
\text { angle }\end{array}$ \\
\hline $550339 \mathrm{a}$ & 17.8 & 15.3 & 15.4 & 11.8 & $78^{\circ}$ \\
\hline $550339 \mathrm{~b}$ & 16.0 & 13.9 & 14.0 & 10.0 & $81^{\circ}$ \\
\hline $550339 c$ & 15.4 & 13.5 & 12.6 & 9.6 & $82^{\circ}$ \\
\hline $550339 \mathrm{~d}$ & 13.5 & 12.0 & 11.7 & 8.2 & $81^{\circ}$ \\
\hline $5.50339 \mathrm{C}$ & 8.0 & 7.2 & 7.5 & 3.9 & $84^{\circ}$ \\
\hline
\end{tabular}

Locality.-Anton Bruun Cruise 9, stations 444, $445,447,465$.

Diagnosis.-Large Frenulina with advanced loop and three blood red bands of irregular color blotches on a mat of cream white.

TYPES.-Holotype: USNM 550339a. Figured paratypes: USNM 550339b, d, g-j; 550340a. Unfigured paratypes: USNM 550339 c, e, f.

COMPARISON.-The only species of this genus available for comparison are Frenulina sanguinolenta (Gmelin) and "Frenulina" alcocki (Joubin). Frenulina cruenta is much larger than the former, usually paler in its yellowish parts, the color banding is more intense, and the bands are better defined. In addition slight differences occur at the beak and in the cardinalia as well as the loop. The cleltidial plates of $F$. cruenta are conjunct, whereas those of $F$. sanguinolenta are usually disjunct. The cardinalia of $F$. sanguinolenta are usually characterized by a fairly strong development of inner hinge plates in the adult, which are lacking from the Indian Ocean species. The latter also has sessile plates in the apex of the dorsal valve, which are lacking or very slightly developed in $F$. sanguinolentr. The loop of $F$. cruenta is more advanced than that of $F$. sanguinolenta, as evidenced by the length and open character of the distal parts of the clescending and ascending branches and also by the rather slender attachment of the hood to the septal attacliments.

Although the loops of " $F$." alcock $i$ and $F$. cruenta are nearly at the same stage of development, many 
differences between the two species are apparent. The former is pale brownish yellow and completely without any red color. The deltidial plates are disjunct and the sessile plates at the posterior of the dorsal valve are more strongly developed than in $F$. cruenta. Furthermore " $F$." alcocki is larger, rounded, and less deep than $F$. cruenta. It is also here assigned to a new genus because of its more advanced loop.

Discussion.-A complete series of the growth stages of this species was not obtained. The smallest specimen is $4.5 \mathrm{~mm}$ long (USNM 550339i, Plate 6: figure 9); and the loop consists of an oblique hood mounting a pillar-like septum, and the broad descending lamellae attached along the side of the pillar-like septum and distally to the anterior end of the hood. The latter is shallow, with its lower sides-forming a wide angle, and open for most of its length. The cover that is at the proximal end of the structure is narrow and forms a small ring. The hood has a narrow opening at the posterior end.

A specimen $7 \mathrm{~mm}$ in length (USNM 550339j, Plate 6: figures 10-13) has the loop in the frenuliniform stage. The hood has now been largely resorbed and the ascending branches are united with the descending and separated by wide lacunae. The remnant of the hood is still a ring and still attached to the remnant of the septal pillar. A specimen $8 \mathrm{~mm}$ long (USNM 550339k) is longer, but still retains the proximal ring, and the ring is attached to the septum. A specimen $10 \mathrm{~mm}$ long (USNM $550339 \mathrm{~m}$ ) has the proximal ring, but the attachment to the septum is smaller and resorption longitudinally is taking place. The next stage is shown by a specimen $12 \mathrm{~mm}$ long (USNM $550339 \mathrm{n}$ ). In this the lower part of the ring is no longer joined directly to the septum, but has been spread laterally and joined to the septum by straight bars. The loop is now essentially that of adult Frenulina.

In the largest adult loop (specimen USNM $550339 \mathrm{~b}$, Plate 6: figures 4-8) the attachments between the septum and the descending branches are long and very slender. At the junction of the descending branch and the crosspiece is the attachment that fastens the crosspiece and ascending elements which were a part of the early ring. These attachments are now narrow ribbons, but the transverse band of the loop is broad at the angles where lamellae attaching the loop to the crosspieces are given off. The transverse ribbon is slender in the middle between the two lateral expansions. This is quite unlike the adult loop of Frenulina, in which the lateral attachments between descending and ascending loop branches are very broad. Furthermore the crosspieces attaching the descending branches to the septum are broad. The adult loop is thus strongly laqueiform.

\section{Compsoria, new genus}

Shell attaining a length slightly less than an inch, rounded oval to subpentagonal in outline; inequivalve, the ventral valve having the greater depth; lateral commissure nearly straight; anterior commissure rectimarginate, but with faint sulcation in some specimens. Beak erect, short; foramen large, submesothyridid; deltidial plates conjunct, readily visible. Surface smooth; punctae closely crowded; color white to faint pink.

Ventral valve with strong teeth supported by thick dental plates. Muscle field bilobed; diductor scars elongated and divergent, bounded by a ridge extending anteriorly from the dental plate. Pedicle collar minute or absent; pallial sinuses not impressed.

Dorsal valve with strong socket ridges, but narrow and slightly concave; crural bases flat but stout; crural process short, acute, located about halfway between hinge plate and hood; descending lamellae long; ascending branches expanding to form a short hood which is attached to the descending branches by a moderately wide ribbon. Descending branches attached to the median septum by slender bands. Lophophore plectolophus.

TyPE-sPEC1Es.-Compsoria suffusa, new species.

Diagnosis.-This genus is closest to Frenulina and Laqueus, perhaps intermediate between the two in the development of its loop. It differs from Frenulina in a number of small characters: it has conjunct deltidial plates, whereas those of Frenulina may or may not be disjunct; it is without the characteristic color bands; the septum of the dorsal valve extends nearly to the apex, without any marked thickening or junction with the crural bases; the loop is more advanced than that of largest Frenulina; the anterior margin is rectimarginate, whereas that of Frenulina is gently and narrowly sulcate or rectimarginate. 
Compsoria differs from Laqueus in having a stronger hoodlike transverse band of the loop, suggesting a slightly less advanced stage of development than usual in Laqueus. The bands connecting the ascending and descending branches of the loop are wider than usual in Laqueus. The median septum of Laqueus in adult shells meets and supports the plates forming the floor of the notothyrial cavity. In the very young Laqueus, the median septum approaches the notothyrial cavity, but the flooring plates of the adult are a secondary development. The same is true in Compsoria, but flooring plates are only infrequently developed so that the cardinalia are intermediate between Frenulina and Laqueus. The flooring plates of Compsoria are usually in the form of a callus which may or may not be laterally excavated.

Discussion.-The collection contains only a few specimens of C. suffusa, but they are sufficient to give a clear idea of the development of the loop and other anatomical details. To this genus must be added Frenulina alcocki (Joubin 1906), originally described as belonging to the genus Kingena but later placed in Frenulina by (Dall). This is a yellowish white shell having a laqueiform loop and coming from the Indian Ocean just southwest of the south apex of India.

Etymology.-The generic name Compsoria is derived from the Greek word "kompsos," meaning elegant.

\section{Compsoria alcocki (Joubin)}

Plate 7: Figures 22-25

K'ingena alcocki Joubin, 1906:529.-Dall, 1920:337.

This species was not figured by Joubin except for the loop, which is illustrated by a large drawing indicating a specimen with somewhat more advanced loop stage than the two specimens in the national collection. The exterior of this species is somewhat suggestive of Compsoria suffusa, new species, but is much rounder. The foramen is large and the deltidial plates disjunct. The anterior commissure is rectimarginate.

As pointed out by Jackson (1921:46, first footnote) and Thomson (1927:242), the loop is laquaeiform. The diagram furnished by Joubin indicates a loop farther toward that of Laqueus than illustrated by specimens in the national collection. An example from the type locality has a remnantal hood, having a narrowed opening posteriorly, and broad descending branches. The loop, because of the well-marked hood, is less advanced than that seen in adult Laqueus, but more advanced than the loop of old adult Frenulina. The anterior lacunae are large but have not obliterated the hood (see Plate 7: figures 24, 25).

Dall (1920:337) lists "Kingena" alcocki from the Sulu Sea and the Indian Ocean. Two specimens are in the national collection, both received from Blochmann: USNM 111056 from the Sulu Sea and USNM 227823 from the Indian Ocean, latitude $8^{\circ} 23^{\prime} \mathrm{N}$, longitude $76^{\circ} 28^{\prime} \mathrm{E}$, southwest of the southernmost point of India. Regarding the first specimen, Helmcke (1940:278) points out that the Valdivia did not operate in the Sulu Sea and that the specimen must have been collected by the $\mathrm{Si}$ boga Expedition. It is not, however, listed by Jackson and Stiasny (1937) in their report on the brachioporls of the Siboga Expedition. Further, in connection with this specimen, Helmcke (1940:278) quotes from a letter to Dall dated December 11, 1906: "Vor kurzem erhielt ich eine ganz besondere Form . . [?] aus dem Indischen Ozean, eine rezente Kingenia [sic], allerdings nur trokene schalen. Auch von diesen werde ich ihnen in einiger Zeit ein Examplar schicken." Specimen 111056 was cataloged by the Museum on October 24, 1908, and must certainly be the specimen that Blochmann was sending to Dall. But in his letter Blochmann definitely says the specimen is from the Indian Ocean.

The second specimen (USNM 227823) that bears the label Kingena alcocki Joubin was received from Blochmann and was recorded on October 9, 1911. A letter from Blochmann to Dall dated September 6, 1911, informs Dall: "Nun sende ich Ihnen ein Examplar Kingena alcocki Joub. Fundort: $8^{\circ} 23^{\prime} \mathrm{N}$, $76^{\circ} 28^{\prime}$ Ost $187 \mathrm{~m}$. Ich habe diese Art nun auch in dem material der Siboga von $6^{\circ} 5^{\prime} \mathrm{N}, 121^{\circ} 19^{\prime}$ Ost $275 \mathrm{~m}$ gesehen. Leider habe ich sich zur zeit kein besseres Examplar." This specimen is from the same locality as Joubin's material. Blochman does not say that he is sending a specimen from the Siboga material, only that he has seen such a specimen in the Siboga collections. The fact that Jackson and Stiasny do not report $K$. alcocki in their lists suggests that Blochmann mistook another species, such as Iolonica hedleyi, for the Indian Ocean form. 
Blochmann also tells Dall in another letter that he has Dallina floridana in the Siboga collections, but Jackson and Stiasny identified it as Campages asthenia Dall.

Comparison of the two National Museum specimens shows them to be alike. They are white in color and the one labeled from the Indian Ocean is partially covered by an agglutinated worm tube. Joubin (1906:529) remarks on the abundance of worm tubes covering the specimens in his collection. Specimen 111056 (attributed to the Sulu Sea by Dall bears on its clorsal valve remnants of a worm tube that compare exactly with the specimen from the Indian Ocean. Joubin (1906:530) also states that he sent several specimens of his species to Blochmann at Tubingen. In all probability Blochmann shared these with Dall. It seems unlikely from the above that Kingena alcocki comes from the Sulu Sea, and it should be regarded as a mistake in labeling.

\section{Compsoria suffusa, new species}

Plate 7: figures 26-44; Plate 8: figures 1-10

Large for the genus, longer than wide, elongate oval in outline; shell thin and delicate; sides rounded; ventral valve the deeper of the two; maximum width at midvalve; anterior narrowed and somewhat truncated; posterolateral extremities forming an angle between $80^{\circ}$ and $90^{\circ}$. Anterior commissure rectimarginate. Beak ridges strong; foramen large, mesothyridid; deltidial plates conjunct. Surface smooth except for strong concentric lines of growth. Color pale pink.

Ventral valve evenly and moderately convex in lateral profile; anterior profile strongly domed and with steeply sloping sides. Umbonal region narrowly swollen, the swelling continued to midvalve, after which the anterior slope is flattened. Anterolateral extremities defining short, narrow, swollen but poorly defined anterior ridges. Lateral slopes convex, moderately steep.

Dorsal valve gently convex in lateral profile and with the anterior profile broadly and gently convex. Median region moderately swollen but anterior flattened; umbonal region moderately swollen.

Ventral interior with short but well developed dental plates. Dorsal valve with a large cardinal process and advanced frenuliniform loop.
Measurements in millimeters:

\begin{tabular}{|c|c|c|c|c|c|}
\hline $\begin{array}{l}\text { USNM } \\
\text { specimens }\end{array}$ & Length & $\begin{array}{c}\text { Dorsal } \\
\text { valve } \\
\text { length }\end{array}$ & $\begin{array}{c}\text { Maximum } \\
\text { width }\end{array}$ & Thickness & $\begin{array}{c}\text { Apical } \\
\text { angle }\end{array}$ \\
\hline $550348 a$ & 19.5 & 17.0 & 17.0 & 10.7 & $89^{\circ}$ \\
\hline $550349 \mathrm{a}$ & 20.6 & 18.6 & 16.8 & 12.0 & $83^{\circ}$ \\
\hline
\end{tabular}

Localities.-Anton Bruun Cruise 7, stations $371 \mathrm{E}, 371 \mathrm{~F}, 373 \mathrm{~B}$.

Diagnosis.-Large Compsoria with suffused, delicate pink anterior coloration and elongate oval outline.

TYPES.-Holotype: USNM 550348a. Figured paratypes; USNM 550348b, 550349a-d; 550441.

Comparison.-The only species of this genus to which comparison can be made is $C$. alcocki (Joubin). From this species it differs in being more elongated, in having more convex valves, in having conjunct rather than disjunct deltidial plates, and in having the anterior end truncated rather than broadly rounded as in $C$. alcocki.

Discussion.-Two immature specimens give an idea of the development of the loop. Specimen USNM 550349c (Plate 8: figures 3, 4) is $6 \mathrm{~mm}$ long and has an obliquely elongated hood with a broad posterior band. Anteriorly the anterolateral elements of the loop are just beginning to form the lacunae characteristic of the frenuliniform loop stage. A second specimen (USNM 550349d, Plate 8: figures $5-8$ ) is $8 \mathrm{~mm}$ long and still preserves the elongated compagiform hood, but the anterolateral elements are widely open. The posterior ring formed by the hood and the attachments to the septum are very narrow. Specimen USNM 550349b (Plate 8: figures 9, 10) is $11 \mathrm{~mm}$ long, and the loop is an elongated frenuliform stage with the ascending and descending branches long and thin, the hood is still retained, and the attachments to the descending branches are wide and stout. The loop is tending toward the laquaeiform stage.

\section{Family TEREBRATELLIDAE W. King, 1850}

\section{Genus Terebratella D’Orbigny, 1847}

\section{Terebratella rubiginosa Dall}

Prate 3: Figures 21-26

Terebratella sp.-Dall, 1870:122, pl. 6: fig. 4.

Terebratella suffusa Dall [not Reeve] 1871:65. 
T. rubiginosa Dall, 1873:135.-Davidson, 1886-1888:91, pl. 16: fig. 19.-Dall, 1895:727.-Thomson, 1927:293.-Jackson, 1952:35

Considerable doubt has been expressed as to the geographic occurrence of this specimen (Davidson, 1887:91) at the Cape of Good Hope in Simmons Bay as claimed by Dall. It is the only Terebratella thus far reported from the $\Lambda$ frican realm. Comparison with other species of the genus shows it to be closest to $T$. enzenspergeri Blochmann, also noted by Jackson (1952:35). Reference is made by Blochmann to " $T$. dorsata" from Kerguelen Islands, figured by Davidson (1880) in the Challenger report (Plate 4: fig. 4), which he regards as a specimen of his species $T$. enzenspergeri. This figure is of a specimen almost identical in size and form to $T$. rubiginosa. It is possible that $T$. rubiginosa may have come from Kerguelen Island and that $T$. enzenspergeri should be a synonym of it.

TYPEs.-Holotype: USNM 5110.

\section{Literature Cited}

Adams, A., and A. L. Recve

1850. Mollusca. Part I in Zoology of the Voyage of H. M. S. Samarang. Pagc 72, plate 21: figure 5. London.

Alcock, A.

1894. A New biachiopod. In Natural History Notes from the Royal Indian Marinc Survey Stcamer Investigator, (2), No. 13. Journal of the Asiatic Society of Bengal 63 (2) 2:139-140, plate 8 .

1902. A Naturalist in Indian Seas, or Four Years with R. I. M. S. Ship "Investigator." 283 pages. London.

Atkins, $D$.

1061 The Generic Position of the Brachiopod Megerlia echinata (Fischer and Oehlert). Journal Marine Biological Association, United Kingdom, 41:89-94.

Picecher, C. E.

1893. Revision of the Families of Loop-bcaring Brachiopoda. Transactions of the Connecticut Academy of Arts and Sciences, 9:376-399, 3 plates.

Blochmann, F.

1906. Neuc Brachiopoden der Valdivia und Gaussexpedition. Zoologische Anzeiger, 21/22:690-702.

Chun, C.

1900-1903. Brachiopoda. In Aus den Tiefen des Weltmeeres, 1, 2. Pages 435-436. Jena.

(noper, G. A.

1959. Gencra of Tertiary and Recent Rhynchonelloid Brachiopods. Smithsonian Miscellaneous Collections, $139(5)$ : 90 pages, 22 plates.

Dall, W. H.

1870. A Revision of the Terebratulidae and Lingulidac, with Remarks on the Description of Some Recent
Forms. American Journal of Conchology, 6 (2):88 I68, plates 6-8.

1871. Report on the Brachiopods Obtained by the United States Coast Survey Expedition, in Charge of L. F. Ponrtales, with a Revision of the Craniidae and Discinidac. Bulletin of the Museum of Comparalive Zoology, Harvard, 3 (1): 45 pages, 2 plates.

1895. Report of Mollusca and Brachiopoda Dredged in Decp Water, Chiefly near the Hawaiian Islands, with Illustrations of Hitherto Unfigured Species from Northwest America. Proceedings of the United States National Museum, 17 (1032) [brachiopods, pagcs 713-729, plates 30-32].

1910. Report on the Brachiopods Obtained from the Indian Ocean by the Sealark Expedition, 1905, No. XVII. The Transactions of the Linnaean Society of London, 13 (3) :439-441, plate 26.

1920. Annotated List of the Recent Brachiopoda in the Collection of the United States National Museum, with Descriptions of Thirty-three New Forms. Proceedings of the United States National Museum, 57 (2314) :261-377.

Daviclson, $\mathrm{T}$.

1880. Report on the Brachiopoda Dredged by H. M. S. Challenger During the Years 1873-1878. In Report . . Challenger Expedition. Zoology, 1:1-67, 4 plates.

1886-1888. A Monograph of Recent Brachiopods. Trans"ctions of the Linnaean Society of London, 4, Zoology, I-III: 248 pages, 30 plates.

Deshayes, G. P.

1863. Calalogue des Mollusques de l'ile de la Réunion (Bourbon). 44 pages, 14 plates. Paris.

Fischer, P., and D. P. Ochlert

1891. Brachiopocles. In Expéditions scientifiques du Trar'ailleur et du Talisman pendant les années 18801883. 140 pages, 8 plates. Paris.

Hatai; K.

1938. The Cenozoic Brachiopods of Northeast Honsyu, Japan. Saito Ho-on Kai Museum Research BulleIin 16:89-246, 5 plates.

1940. Cenozoic Brachiopoda from Japan. Science $R \boldsymbol{e}$ ports of the Tóhoku Imperial University, second scries (Geology) 20: 413 pagcs, 12 plates.

Helmcke, J. G

1938. Dic Brachiopoden des zoologischen Museums zu Berlin. In Sitzungsberichte der Gesellschaft naturforschender Freunde zu Berlin für 1938:221-268.

1939. Brachiopoda. In $W^{T}$. Kükenthal and $T$. Krumbach. Handbuch der Zoologie, Berlin, 3(2):139-258, fig. ures 152-271.

1940. Dic Brachiopoden der Deutschen Tiefsce Expedition. In Wissenschaftliche Ergebnisse der deutschen Tiefsee-Expedition auf dem Dampfer "Valdivia" 189s-1899, 24 (3) :217-316, 43 figures.

Jackson, J. W.

1921. On the Occurrence of Lusitanian Brachiopods in the Persian Gulf. Annals and Magazine of Natural History, series 9, 7:40-49. 
1952. A Revision of Some South African Brachiopoda, with Descriptions of New Species. Annals of the South African Museum, 41 (1): 40 pages, 3 plates. Jackson, J. W., and G. Stiasny

1937. The Brachiopoda of the Siboga Expedition. In Siboga Expeditie, 27: 20 pages, 2 plates. Leiden. Joubin, M. L.

1906. Note sur un brachiopode nouveau de l'Océan Indien, Kingena Alcocki. Bulletin du Muséum d'Histoire Naturelle, 12:529-532.

King, $W$.

1871. On Agulhasia Davidsonii, a New Palliobranchiate Genus and Species. Annals and Magazine of Natural History, series 4, 7:109-112, plate 11 .

Licharev, B. K.

1960. Brakhiopody. Introduction in Osnovy Paleontologii. Pages 115-171.

Muir-Wood, H. M.

1959. Report on the Brachiopoda of the John Murray Expedition. In The John Murray Expedition 193334 Science Reports 10(6):283-317, 5 plates.

1965. Mesozoic and Cenozoic Terebratulidina. In Williams, et al., 1965, pages H762-816.

Philippi, R. A.

1836. Ennumeratio Molluscorum Siciliae cum Viventium tum in Tellure Tertiaria Fossilium quae in Itinere suo Observatit, 1: 97 pages, plate 6, figures $15 a \cdot g$.
Reeve, L. A.

1860. Brachiopoda. Volume 13 in Conchologia Iconica, or Figures and Descriptions of Molluscous Animals. 23 volumes. London.

Thomson, J. A.

1926. A Revision of the Subfamilies of the Terebratulidae (Brachiopods). Annals and Magazine of Natural History, series 9, 18:523-530.

1927. Brachiopod Morphology and Genera (Recent and Tertiary). New Zealand Board of Science and Art, Manual 7: 338 pages, 2 plates.

Turton, W. H.

1932. Brachiopoda. In The Marine Shells of Port Alfred, S. Africa. Pages 259-260, plate 70.

Williams, A., et al.

1965. Brachiopoda. In R. C. Moore, editor, Treatise on Invertebrate Paleontology. Part H, 927 pages, 746 figures.

Yabe, $\mathrm{H}$, and $\mathrm{K}$. Hatai

1934. The Recent Brachiopod Fauna of Japan (1), New Genera and Subgenera. Proceedings of the Imperial Academy of Tokyo, 10 (9):586-589.

Zezina, O. N.

1965. The Distribution of the Deep Water Brachiopod Species, Pelagodiscus atlanticus (King). Okeanologiya, 5 (2) :345-358. 


\section{PLATE 1}

Megerlia echinata (Fischer and Ochlert): I, Ventral view of the exterior, showing the amphithyrid foramen, $\times 1$, figured specimen USNM $173834 ; 2,3$, dorsal and ventral views of the same specimen, showing the granulations and raclial costellac on the dorsal exterior, $\times 3$ [latitude $36^{\circ} 43^{\prime} \mathrm{S}$, longitude $13^{\circ} 36^{\prime} \mathrm{F}$, southwest of the Cape of Good Hope, South Africa].

Cryploporn curiosa, new species. 4, Ventral view of a specimen attached to a coralline encrusted ventral valve of Frenulina cruenla, $\times 4$, paratype USNM 550360 [Anlon Bruun 9 station 465]; 5, 6, clorsal views of two complete specimens, showing the winglike deltidial plates, median septum, muscles, genital glands, and circinate lophore, all seen through the shell in alcohol, $\times 10$, paratypes USNM 550363b, a [Anton Brunn 9, station 444].

Lacnzella mauritiana Dall: 7 , Exterior in dorsal view, showing both valves in contact, $\times 6$, holotype USNM $173593 ; 8,9$, interior of the ventral and dorsal valves, $x^{6}$ of the holotype [off Mauritius Island, Indian Ocean].

Lingula translucida Dall: 10, Ventral view of a complete specimen, $\times 1$, hypotype USNM $150706 \mathrm{a} ; 1 \mathrm{I}$, interior of the dorsal valve, $\times 1$, hypotype USNM $150706 \mathrm{~b} ; 12$, ventral view of a specimen preserving the long pedicle, $\times \mathrm{I}$, hypotype USNM $332782 \mathrm{a} ; 13$, dorsal view of a very large specimen with its anterior setae, $\times 1$, liypotype USNM 332782b [Karachi, Pakistan].

Kraussina species: 14, 15, Exterior of the ventral and dorsal valves, showing obscure radial lines, $\times 8$, figured specimen USNM $550377 ; 16,17$, interior of the ventral and dorsal valves of the same specimen, showing the long pedicle collar and small teeth in the ventral valve and the short septum with its two prongs in the dorsal valve, $\times 8$ [Anton Bruun Cruise 7, station 358A].

Discinisca indicn Dall: 18, Ventral view of a specimen with part of the pedicle valve preserved and showing some muscle marks on the dorsal valve interior, $\times 4$, paralectotype USNM 90305a; 19,20 , ventral view of another specimen with both valves preserved, $\times 1, \times 4$, lectotype USNM $90305 \mathrm{~b} ; 21$, exterior view of the lectotype, $\times 4 ; 22,23$, exterior of another specimen, $\times 1$, $\times 4$, paratype USNM 90305 c; 24,25 , exterior of a large dorsal valve showing ornament, $\times 4$, paratype USNM 90305l [Bombay, India].

Eucalathis fasciculata, new species: 26-28, Interior, dorsal, and ventral views, $\times 10$, of the holotype, USNM 550371, showing the smooth umbonal regions and fasciculate ornament [Anton Bruun Cruise 7, station 363k]. 

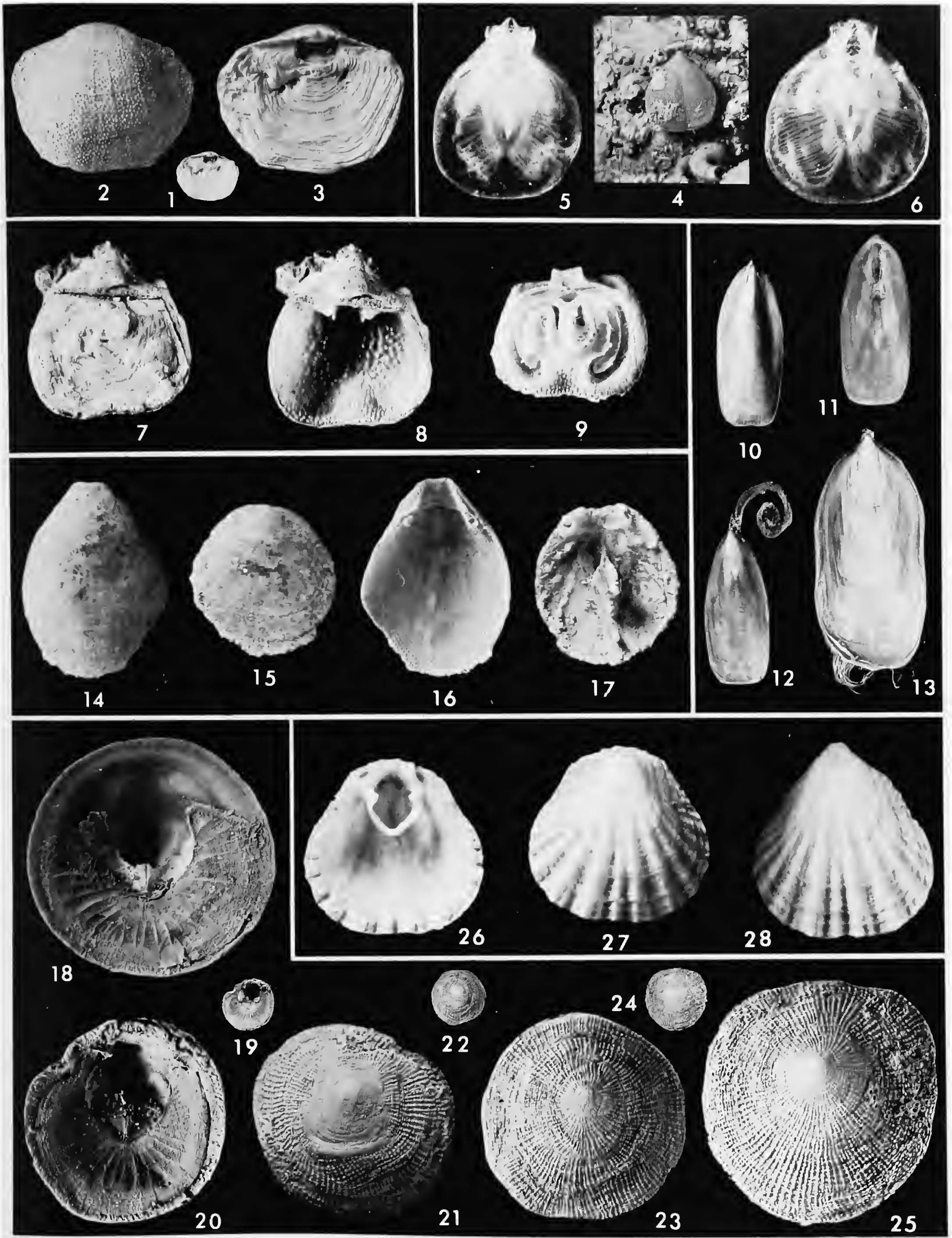


\section{PLATE 2}

Cryptopora curiosa, new species: 1-3, Dorsal, posterior, and side views, showing winged deltidial plates, $\times 10$, paratype USNM 550361a; 4-8, side, dorsal, anterior, ventral, and posterior views, $\times 10$, of another paratype, USNM 550361b [Anton Bruun Cruise 7, station 371G]; 9-12, ventral, side, dorsal, and anterior views, $\times 10$, of a paratype, USNM $550363 \mathrm{a}$, showing fine radial lines; 13-15, ventral, dorsal, and side views of a paratype, showing winged deltidial plates, $\times 10$, USNM 550363b [Anton Bruun Cruise 9, station 444]; 16-20, ventral, anterior, dorsal, posterior, and side views of a large individual, $\times 10$, holotype, USNM 550364 [Anton Bruun Cruise 9, station 447]; 21, 22, interior of the dorsal valve, in ventral and laterally tilted views, $\times 10$, paratype USNM 550362; 23, posterior part of the preceding, enlarged to show crura and median septum, $\times 20 ; 24,25$, interior of the ventral valve counterpart of the preceding, showing the teeth and elaborate winged deltidial plates, $\times 10, \times 20$.

Striarina valdiviae (Helmcke): 26, 27, Exterior of the dorsal and ventral valves, showing fine radial costellae or capillae, $\times 2$, hypotype USNM 549729a; 28,29 , interior of the preceding ventral valve, $\times 4, \times 2$, showing small disjunct deltidial plates and strong teeth; 30, 31, interior of the preceding dorsal valve, $\times 2, \times 4$, showing short falcifer crura; 32-36, posterior, side, anterior, dorsal, and ventral views of a complete specimen, $\times 2$, hypotype USNM 549729b; 37, same as the preceding in dorsal view, $\times 1$; 38, same specimen, $\times 4$, showing the fine costellae [Valdivia expedition, station 165]. 


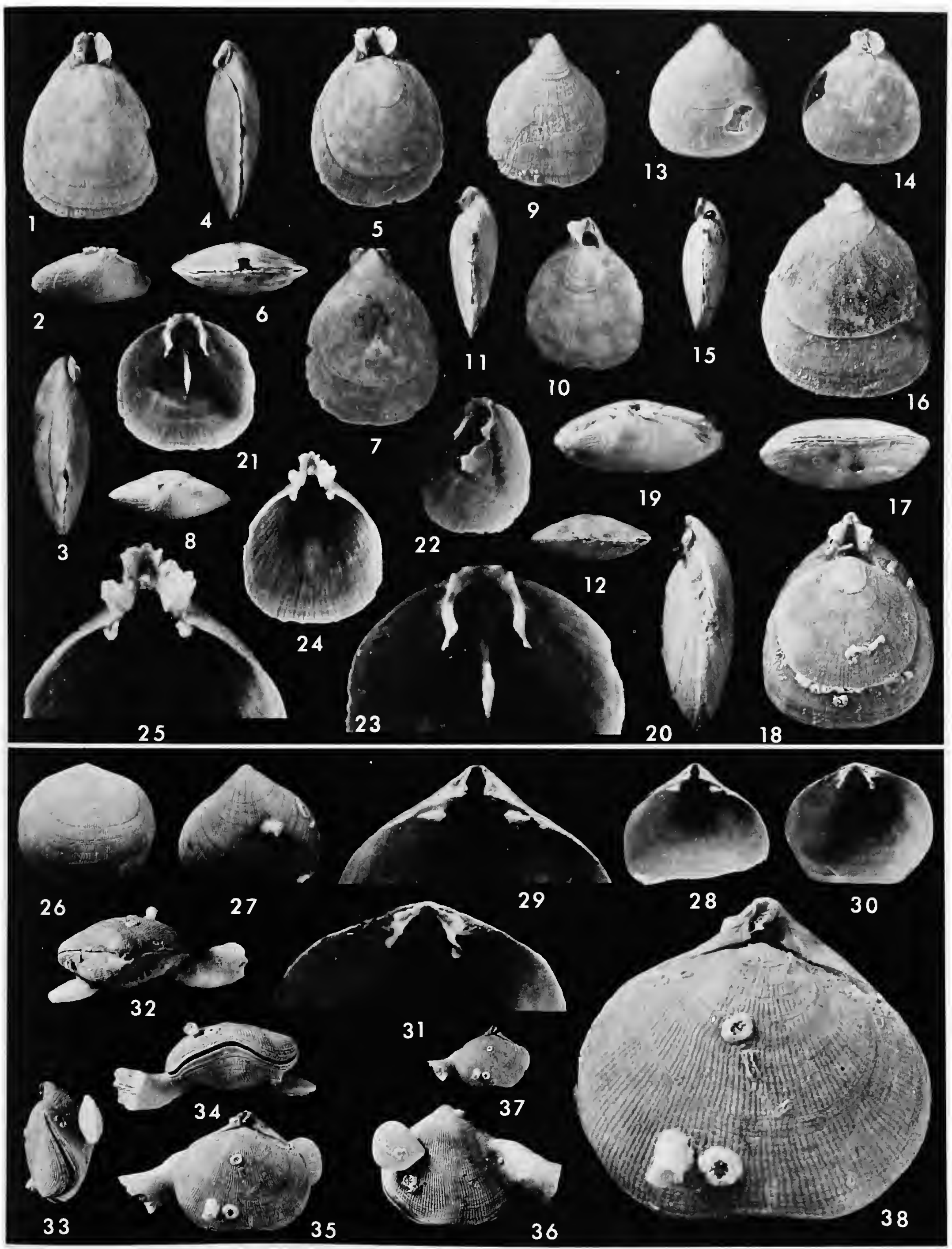




\section{PLATE 3}

Rhytirhynchia sladeni (Dall) : 1-3, Side, anterior, and dorsal views, $\times 1$, of the holotype showing anterior plication, USNM 111086; 4, interior of the dorsal valve of the holotype, showing cardinalia, $\times 3$, [Saya de Malha Banks, Indian Ocean].

Terebratulina species 2: 5-7, Ventral, side, and dorsal views of a complete specimen $\times 3$, figured specimen $550369 \mathrm{a} ; 8$, interior of the dorsal valve, showing characteristic loop, $\times 3$, figured specimen $550369 \mathrm{~b}$ [Anton Bruun Cruise 9, station 444].

Argyrotheca jacksoni, new species: 9-13, Posterior, anterior, ventral, side, and dorsal views of a complete specimen, $\times 10$, USNM 550432 [Reef Ras Muhammad, southernmost Sinai Peninsula, Red Sea].

Nipponithyris nipponensis Yabe and Hatai: 14, Dorsal view of a complete specimen, $\times 1$, hypotype USNM $334769 \mathrm{a} ; 15-17$, side, dorsal, and anterior views, $\times 2$, of the preceding hypotype, showing sulcate anterior commissure; 18-20, laterally tilted, ventral, and posteriorly tilted views of the dorsal interior, showing the early terebrataliiform loop stage, the final stage for the genus, $\times 2$, paratype USNM 334769b [Hakodate, Hokkaido, Japan].

Terebratella rubiginosa Dall: 21-24, Dorsal, anterior, ventral, and side views of the holotype, $\times 1$, USNM 5110; 25, 26, interior of the dorsal and ventral valves, $\times 1$, showing loop and disjunct deltidial plates of the holotype [Simmons Bay, Cape of Good Hope, South Africa? (see text)].

Mergerlia echinata (Fischer and Oehlert): 27-30, Posterior, anterior, dorsal, and ventral views of a small, misshapen specimen, $\times 10$, hypotype USNM 55043la, showing pustules on costellae (compare plate 1: figure 2); 31, the preceding specimen opened to show the immature stage of the loop and the anterior row of tubercles, $\times 10$ [Reef Ras Muhammad, southernmost Sinai Peninsula, Red Sea, less than 10 meters depth].

Terebratulina species 1: 32-34, Side, ventral, and dorsal views of a small complete individual, $\times 3$, figured specimen 550370a; 35 , interior of the dorsal valve, $\times 3$, showing the complete ring of the loop, figured specimen USNM 550370b [Anton Bruun Cruise 1, station 18A].

Kraussina gardineri Dall: 36-40, Posterior, anterior, ventral, side, and dorsal views of the holotype, $\times 1$, USNM 111085; 41, interior of the ventral valve of the holotype, $\times 1$, showing short pedicle collar; 42 , interior of the dorsal valve of the holotype, $\times 2$, showing cardinalia and slender prongs on the median septum [Saya de Malha Banks, Indian Ocean].

Terebratulina meridionalis Jackson: 43-45, Anterior, side, and dorsal views of a complete specimen, $\times 3$, showing the costellate umbonal region, but most of valves anterior to umbones nearly smooth, hypotype USNM 550367 [Anton Bruun Cruise 8, locality 400C]. 

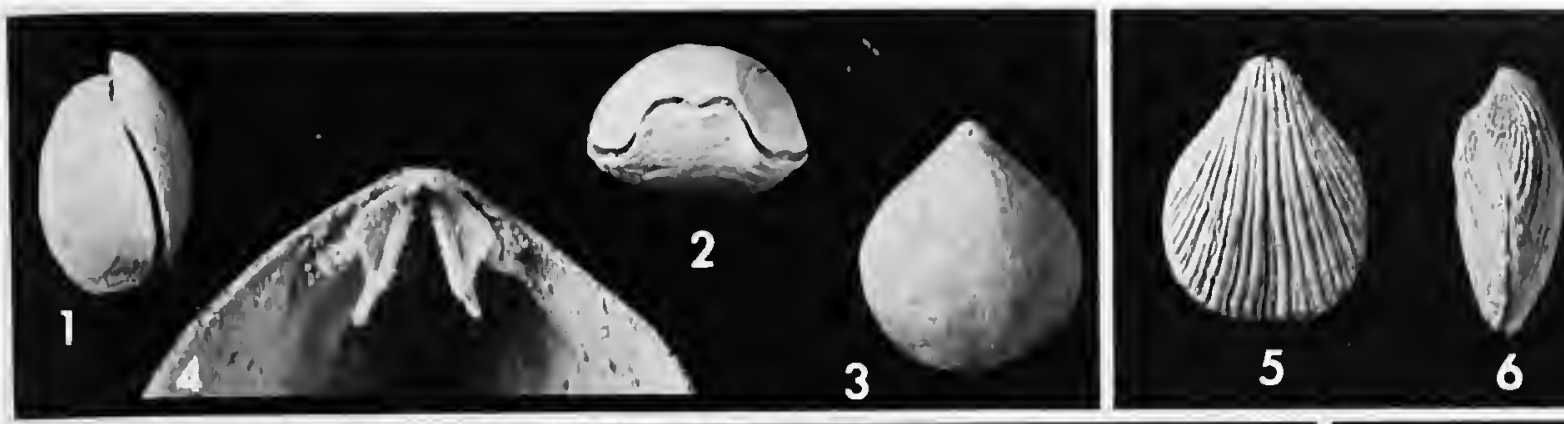

5
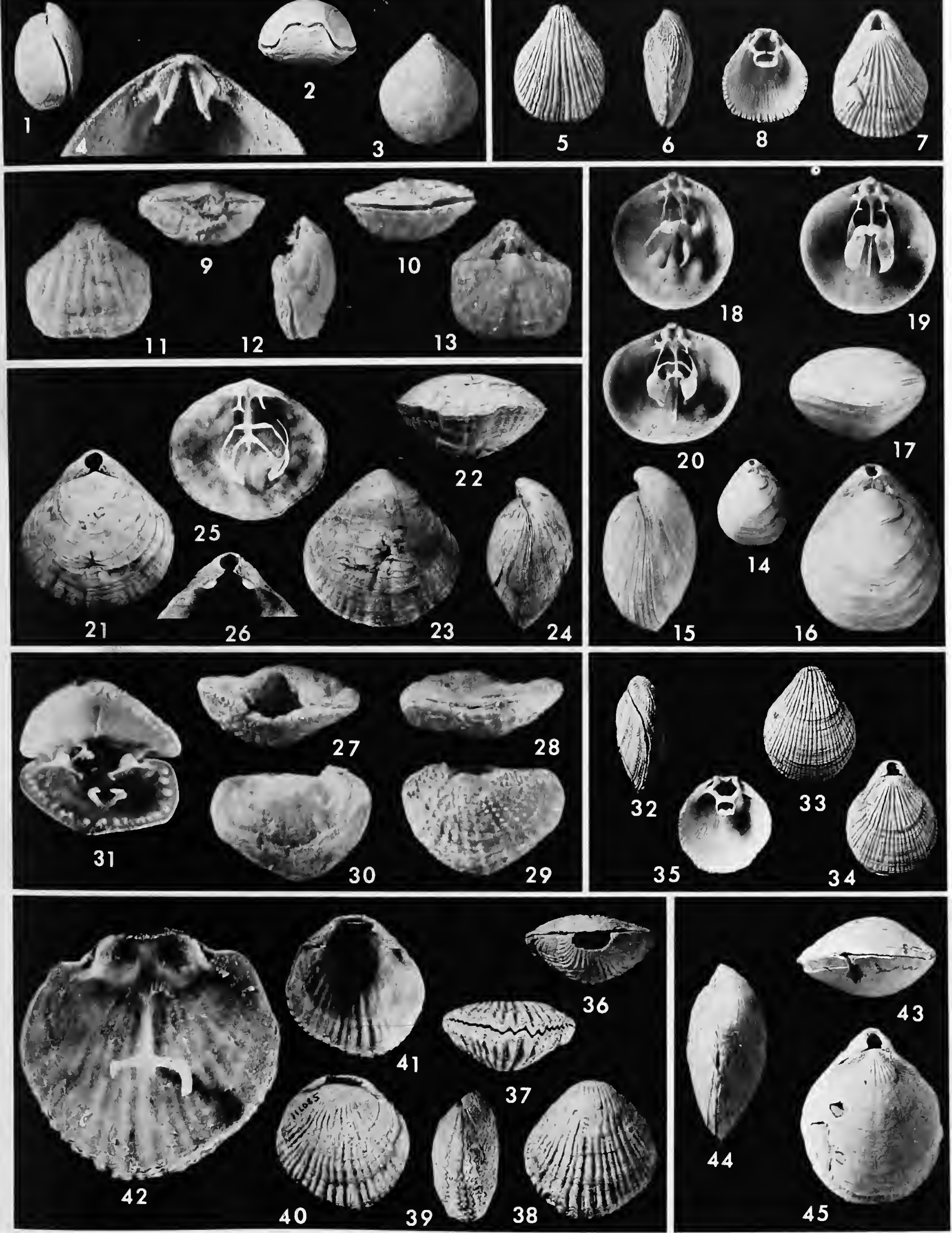


\section{PLATE 4}

Agulhasia davidsoni W. King: 1-4, Ventral, side, anterior, and dorsal views of a complete individual, $\times 4$, hypotype USNM 550408a; 5 , the preceding enlarged, $\times 8$, to show elongate deltidial plates and apical plate; 6-9, anterior, ventral, side, and dorsal views of a specimen smaller than the preceding, $\times 4$, hypotype USNM $550408 \mathrm{~b} ; 10$, dorsal view of the preceding specimen, $\times 8$, showing deltidial plates and apical plate; 11 , interior of the dorsal valve, $\times^{8}$, showing cardinal process and enormous socket ridges, hypotype USNM 550408c; 12, interior of the ventral valve, $\times 8$, showing deltidial plates, and ponderous teeth, hypotype USNM 550408d [Anton Bruun Cruise 7, station $391 \mathrm{H}$ ]; 13, 14, interior of the pedicle and dorsal valves of the same individual, $\times 10$, showing deltidial plates and apical plate, cardinal process, and complete loop (compare with Thomson 1927: 183, figure 52c), hypotype USNM 549456 [Agulhas Bank, South Africa, at 82-110 meters].

Lingula translucida Dall: 15, 16, Ventral views of the paratype and lectotype, $\times 1$, selected from Dall's cotypes, USNM 174003b, a [Java (the only locality information known)].

Gryphus indianensis, new species: 17-19, Anterior, dorsal, and side views, $\times 2$, a rather slender specimen, paratype USNM 550366c; 20, interior of the dorsal valve of the preceding paratype, $\times 3$, showing the loop; 21, dorsal view of the holotype, $\times 1$, USNM 550366a; 22-26, dorsal, anterior, side, posterior, and ventral views, $\times 2$, of the holotype; 27-29, side, anterior, and dorsal views, $\times 2$, of an obese specimen, paratype USNM 550366b; 30, interior of the dorsal valve of the preceding specimen, $\times 3$, showing loop and cardinalia [Anton Brunn Cruise 9, station 465].

Gryphus africanus, new species: 31-34, Ventral, dorsal, anterior, and side views, $\times 4$, of the holotype, USNM 550375a; 35, 36, interior of the ventral and dorsal valves of the holotype, $x^{6}$, showing the narrow beak region and loop, with dorsally directed transverse ribbon; 37,38 , interior of the dorsal and ventral valves of another individual, $\times 6$, paratype USNM $550375 \mathrm{~b}$ [Anton Bruun Cruise 7, station 358A]. 

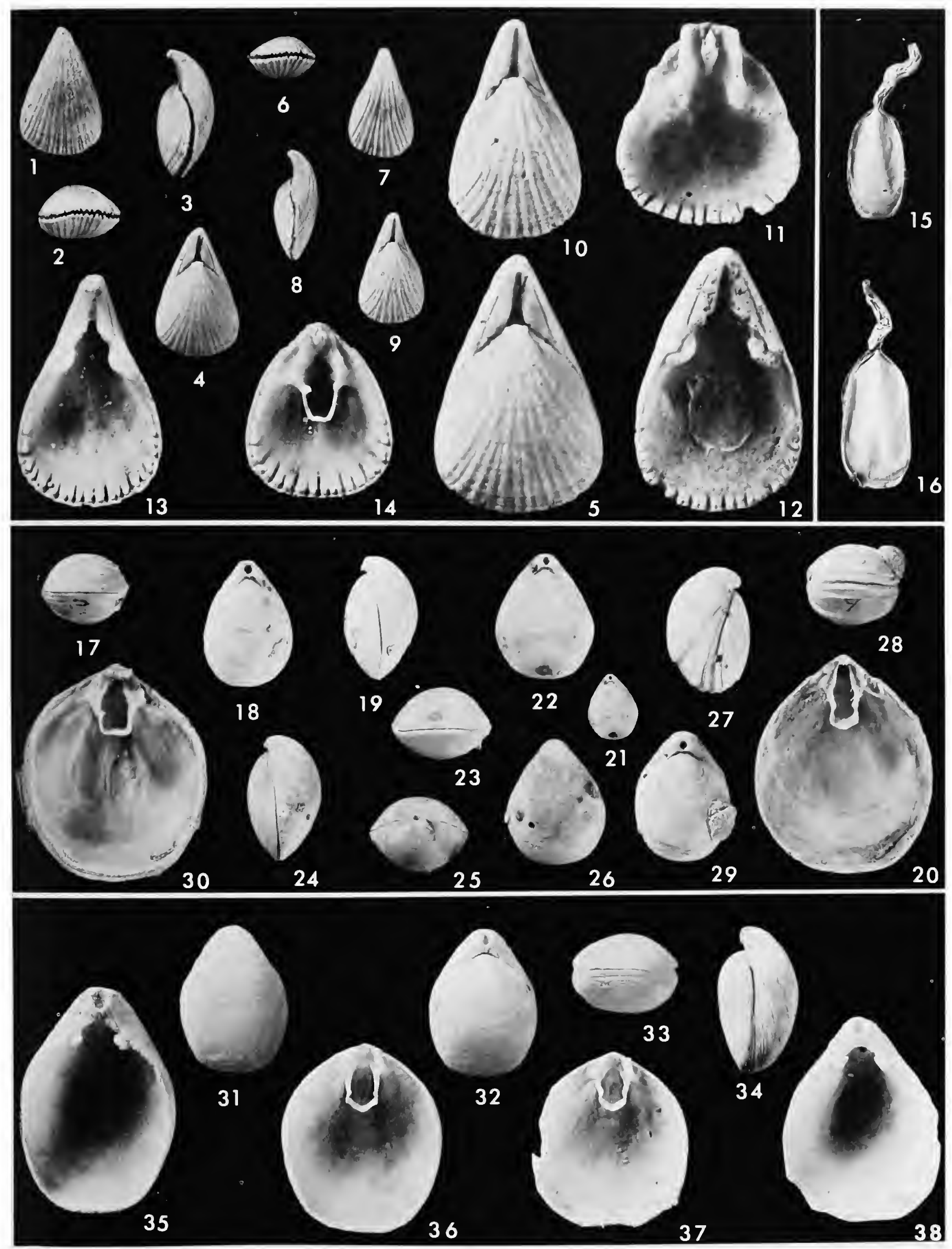


\section{PLATE 5}

Argyrotheca somaliensis, new species: 1-5, Ventral, dorsal, posterior, side, and anterior views. $\times 5$, of the holotype USNM 550346a; 6 , the holotype agape, $\times 5$, showing interior $[$ Anton Bruun Cruise 9, station 447]; 7-9, anterior side, and posterior views of a dorsal interior, $\times 5$, paratype, USNM 550372; 10, ventral view of the interior of the preceding dorsal valve, $\times 10$, showing the loop (partially broken on the right side); 11 , interior of the ventral valve, counterpart to the preceding, $\times 10$, showing the wide teeth and the pits in the medium septum. 12-16, side, anterior, dorsal, posterior, and ventral views of a young specimen, $\chi 4$, paratype USNM 550345a; 17 , interior of the dorsal valve, $\times 8$, showing the loop and cardinalia of the preceding paratype; 18 , interior of the ventral valve of the preceding, $\times 8$, showing deltidial plates, teeth and anterior pits in septum [Anton Bruun Cruise 9, station 445]; 19, interior of another dorsal valve, $\times 10$, showing the loop, paratype USNM 550344 [Anton Bruun Cruise 9, station 444].

Thaumatosia anomala, new species: 20-24, Posterior, anterior, dorsal, side, and ventral views of a young specimen, showing the amphithyrid foramen, $\times 10$, paratype USNM 550347a; 25-29, ventral, dorsal, posterior, side, and anterior views of another paratype, $\times 10$, USNM $550347 \mathrm{~b}$; $30-34$, ventral, posterior, anterior, side, and dorsal views of the holotype, $\times 10$, USNM 550347c, showing amphithyrid foramen; 35 , interior of the ventral valve, showing median ridge and teeth, $\times 20$, paratype USNM 550347d; 36, small specimen, showing the schizolophous lophophore through the shell, $\times 20$, paratype USNM 550347f; 37, interior of the dorsal valve, showing sockets and socket ridges, $\times 20$, paratype USNM 550347e [Anton Bruun Cruise 1, station 18A]. 


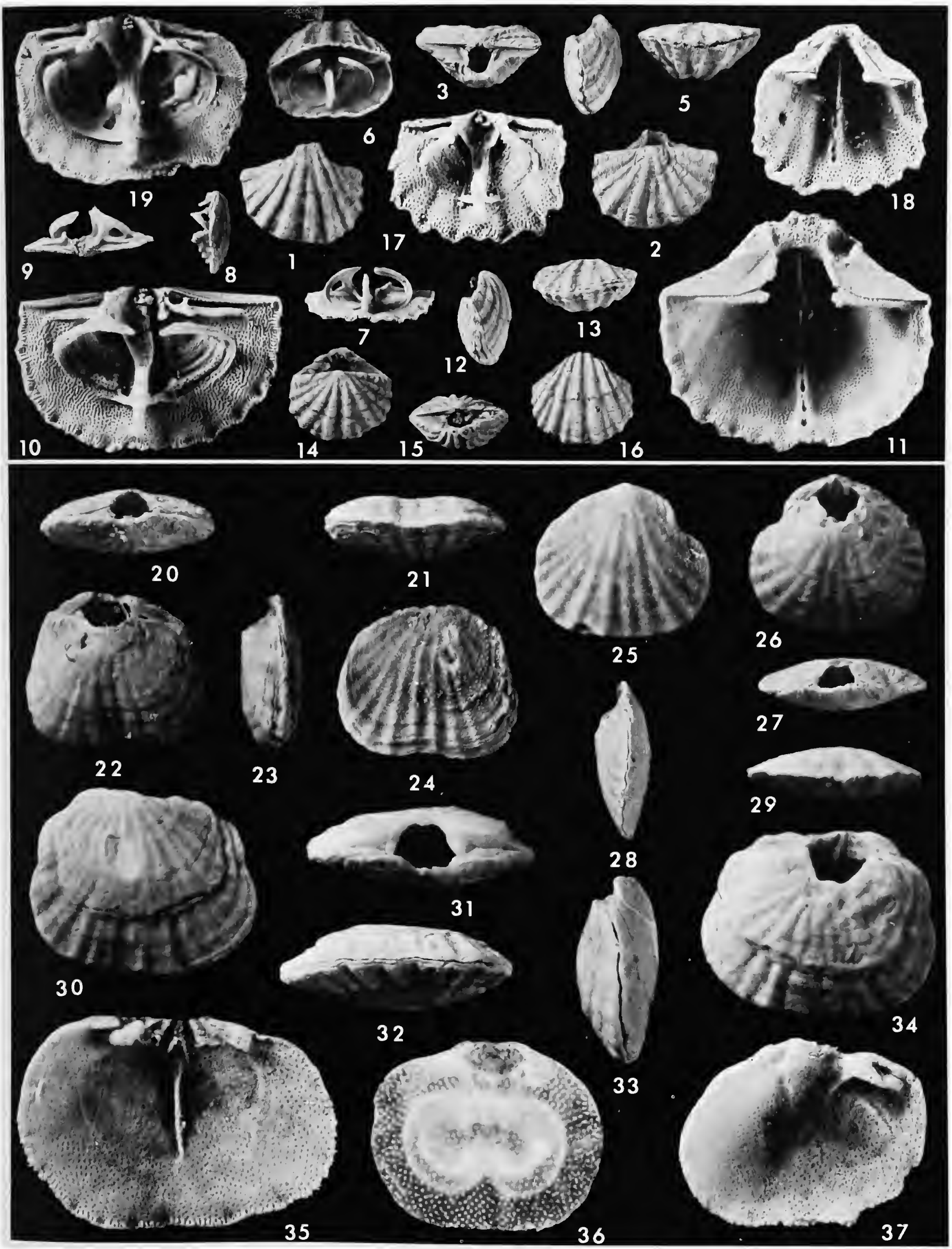




\section{PLATE 6}

Frenulina sanguinolenta (Gmelin): 1, Dorsal view of a complete specimen, showing disjunct deltidial plates and characteristic color pattern, $\times 3$, figured specimen USNM 337539a [Kaneohe Bay, Oahu, Hawaii]; 2, 3, ventral and laterally tilted views of the dorsal interior, showing the loop, note lacunae in anterior part of hood, the final or frenulina stage of loop development, $\times 3$, figured specimen USNM 342205 [Ryukyu Islands, Pacific Ocean].

Frenulina cruenta, new species: 4-7, Posteriorly tilted, laterally tilted, posterior and ventral views of the dorsal valve interior, showing the loop with its remnantal hood and attachment to the descending lamellae, an advanced fernuliniform loop, $\times 2$, paratype USNM $550339 \mathrm{~b} ; 8$, interior of the ventral valve, showing conjunct deltidial plates, $\times 2$, counterpart to preceding specimen; 9 , interior of an immature dorsal valve, showing the hood of the campagiform stage of the loop, $\times 6$, paratype USNM 550339i; 10-13, immature specimen anteriorly tilted, ventral, laterally tilted, and posteriorly tilted views of another immature dorsal valve, showing the loop in an early frenuliniform stage, $\times 3$, paratype USNM $550339 \mathrm{j} ; 14,15$ rubber impression of the interior of a dorsal valve and the specimen from which it was prepared, showing the muscle scars and median septum, $\times 2$, paratype USNM $550339 \mathrm{~h} ; 16$, rubber impression taken from the interior of a ventral valve, showing the muscle scars, $\times 2$, taken from paratype USNM 550339g; 17,18 , side and ventral views of a complete specimen, $\times 1$, paratype USNM 550339d; 19, 20, anterior and dorsal views of the preceding specimen, $\times^{2}$, showing the color pattern; 21-23, dorsal, anterior, and ventral views of a paratype, showing the color pattern, $\times 2$, USNM $550339 \mathrm{~b}$, same specimen figured above in figures 4-8; 24-27, dorsal, anterior, posterior, and side views of a complete specimen, coated with ammonium chloride dust, $\times 1$, holotype USNM 550339a; 28-32, dorsal, posterior, side, anterior, and ventral views of the holotype, $\times 2$, uncoated and showing the color pattern of cream white with blood red splotches [Anton Bruun Cruise 9, station 465]; 33-35, ventral, posterior, and side views of the dorsal valve interior, showing an adult late frenuliniform loop, $\times 2$, paratype USNM $550340 \mathrm{a} ; 36$, posterior of the ventral valve, showing the conjunct deltidial plates, $\times 3$, counterpart of the preceding paratype; 37-41, ventral, anterior, side, posterior, and dorsal views, $\times 1$, of the preceding paratype, coated with ammonium chloride dust; 42 , dorsal view, $\times 1$, of the same specimen without coating and showing the color pattern; 43-45, the same specimen, $\times 2$, in side, dorsal, and anterior views, showing conjunct deltidial plates and nearly rectimarginate anterior commissure [Anton Bruun Cruise 9, station 444]. 

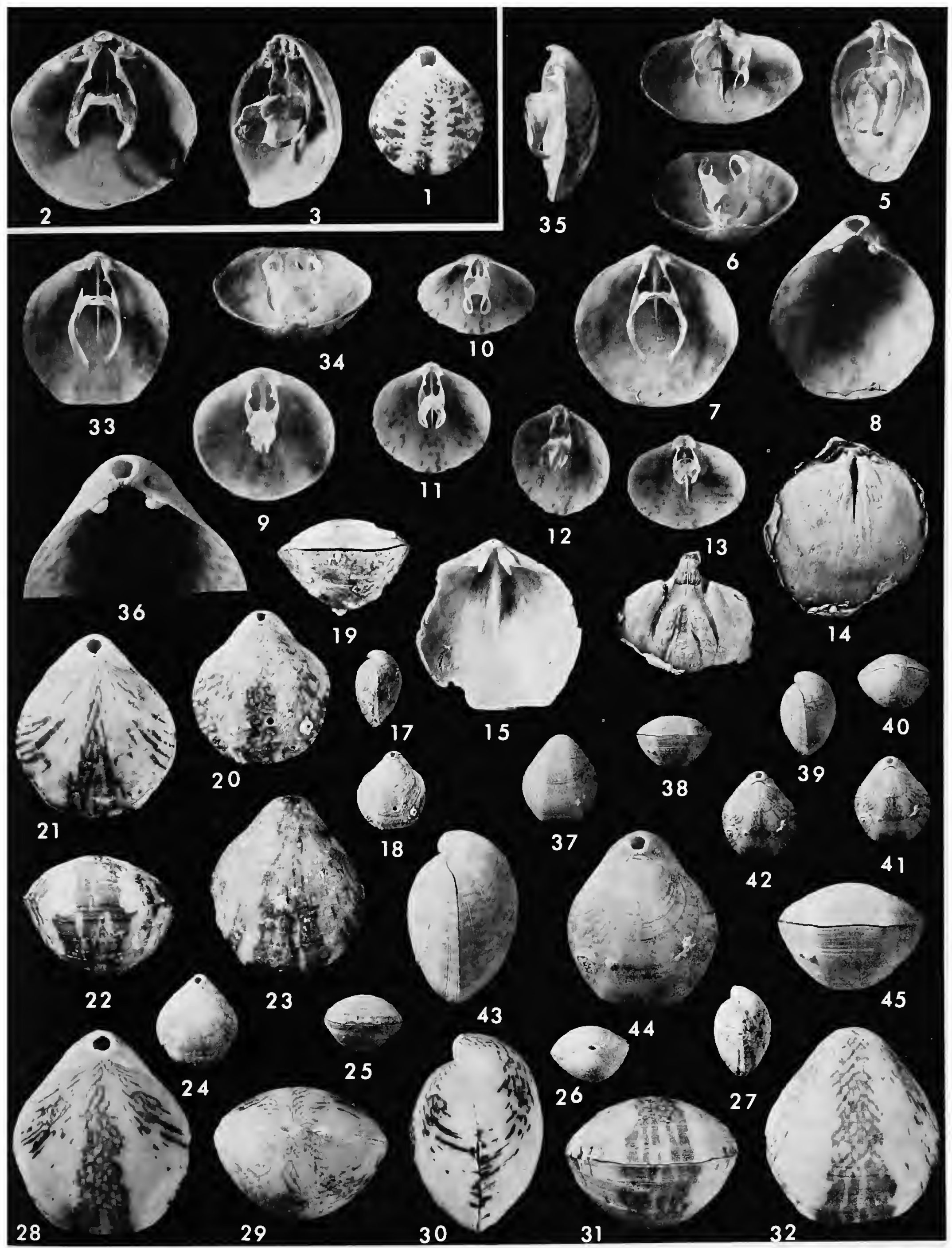


\section{PLATE 7}

Nipponithyris afra, new species: 1-5, side, ventral, dorsal, posterior, and interior views, $\times 2$, holotype USNM 550343a; 6, dorsal view, $\times 1$, of the holotype; 7 , dorsal view, $\times 2$, of another complete specimen, paratype USNM 550343b; 8, 9, interior of a dorsal and ventral valve of the same specimen, showing small cardinal process, median septum, and conjunct deltidial plates, $\times 3$, paratype USNM 550343c; 10,11, rubber impressions prepared from the preceding ventral and dorsal valves, $X^{2}$, showing the muscle scars and pallial impressions [Anton Bruun Cruise 8, station 399B]; 12-16, anterior, side, posterior, dorsal, and ventral views of another complete specimen, $\chi^{2}$, paratype USNM 550342a; 17, dorsal view of the preceding, $\times 1 ; 18,19$, posteriorly tilted and ventral views of a dorsal valve, showing a complete loop in early terebrataliiform stage, $\times 3$, paratype USNM $550342 \mathrm{~b} ; 20,21$, two immature loops tilted slightly laterally and in a late campagiform stage, $\times 4$, paratypes USNM 550342c, d [Anton Bruun Cruise 8, station 398B].

Compsoria alcocki (Joubin) : 22, 23, Ventral and dorsal views of a complete specimen, partially covered by an agglutinated worm-tube, $\times 1$, hypotype USNM 227823; 24, 25, interior of the dorsal valve of the same specimen, showing the loop with hood and struts to the descending lamellae, a loop in early laquaeiform condition, $x^{2}$ [southwest of the southern point of India].

Compsoria suffusa, new species: 26-30, Ventral, side, dorsal, posterior, and anterior views of the holotype, $\times 1$, USNM 550348a; 31-33, anterior, side, and dorsal views of the holotype, $\times^{2}$, showing nearly rectimarginate commissure; 34-38, posterior, ventral, posteriorly tilted, laterally tilted, and side views of the loop of the holotype, $\times^{2}$, an early laquaeiform loop; 39 , interior of the ventral valve of the holotype, $\times 2$, showing conjunct deltidial plates and large foramen [Anton Bruun Cruise 7, station 371F]; 40-44, posterior, dorsal, side, ventral, and anterior views of another complete individual, $\times 1$, paratype USNM 550349a [Anton Bruun Cruise 7, station $371 \mathrm{E}]$. 


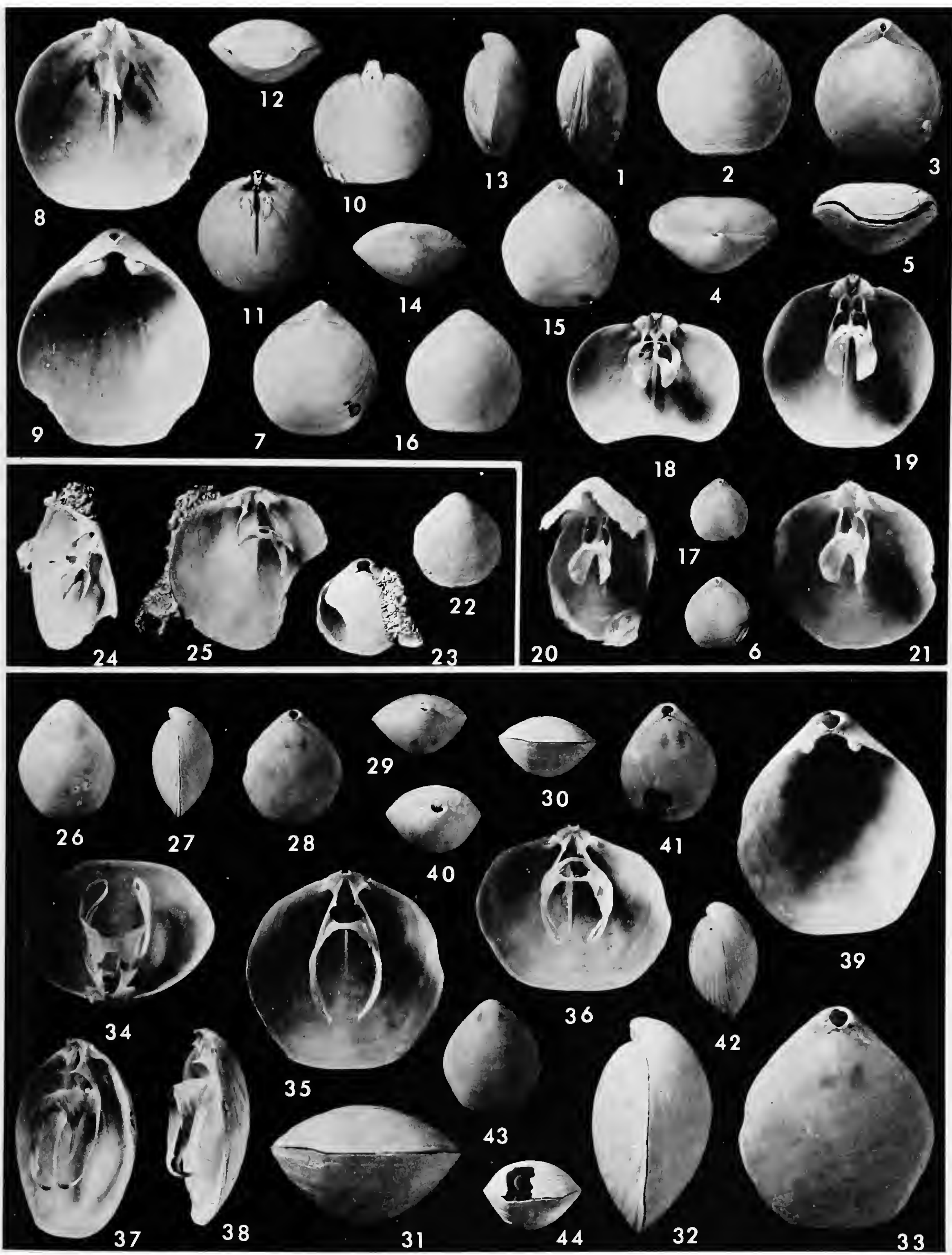




\section{PLATE 8}

Compsoria suffusa, new species: 1 , Dorsal view of a very young specimen, $\times 2$, paratype USNM 550348b [Anton Bruun Cruise 7, station 371F]; 2, dorsal view of a larger but young individual, $\times 2$, paratype USNM 550441 [Anton Bruun Cruise 7, station 373B]; 3, 4, ventral and laterally tilted views of a young specimen with early campagiform loop, and showing the elongated hood, $\times 4$, paratype USNM 550349c; 5-8, posterior, tilted laterally anterior, and ventral views of another paratype, showing hood but with window in the anterolateral parts of the hood, $\times 4$, USNM 550349d; 9, 10, ventral and laterally tilted views of a young adult, showing remnants of the hood, open anterolateral windows in hood, but thick posterior strut attaching hood to descending lamellae, $\times 4$, paratype USNM 550349b [Anton Bruun Cruise 7, station 371E].

Megerlina species: 11, Exterior of the ventral valve showing the ornament, $\times 4$, figured specimen USNM 550378 [Anton Bruun Cruise 7, station 371E].

Frenulina sanguinolenta (Gmelin) : 12-16, Series showing growth of loop from precampagiform (figures $12,13=\times 10$ ) to campagiform (figure $14=\times 6$ ), early frenuliniform (figure 15 $=\times 6$ ) to adult frenuliniform (figure $16=\times 6$ ) stages for comparison with the similar loop of Compsoria above, hypotypes USNM 292546a, b, d, f, and g [off Siran Island, Tawi-Tawi Island, Philippines].

Chlidonophora chuni Blochmann: 17, 18, Interior and exterior of a pedicle valve, $\times 4$, hypotype USNM 550439; 19, 20, interior and exterior of the dorsal valve, counterpart to the preceding specimen, $\times 4$, showing delicate socket ridges and slender descending lamellae of the loop [Anton Bruun Cruise 7, station 363j]; 21-25, posterior, side, ventral, anterior, and dorsal views of a complete specimen, $\times 4$, hypotype USNM 550440 [Anton Bruun Cruise 8, station 399c]; 26, a paratype of Blochmann's opened to show the anteriorly narrowed loop, with its sharp median wrinkle, $\times 4$, USNM 110436a [off the Maldive Islands, southwest of India].

Thecidellina blochmanni Dall: 27-29, Side, ventral, and dorsal views of the holotype, $\times 4$, USNM 227822; 30, interior of the dorsal valve of the holotype, $\times 8$ [Christmas Island, southwest of Java, Indian Ocean].

Thaumatosia anomala, new species: 31, Interior of the ventral valve, showing the teeth and median ridge, figured specimen, $\times 20$, USNM 550376 [Anton Bruun Cruise, station 29]. 

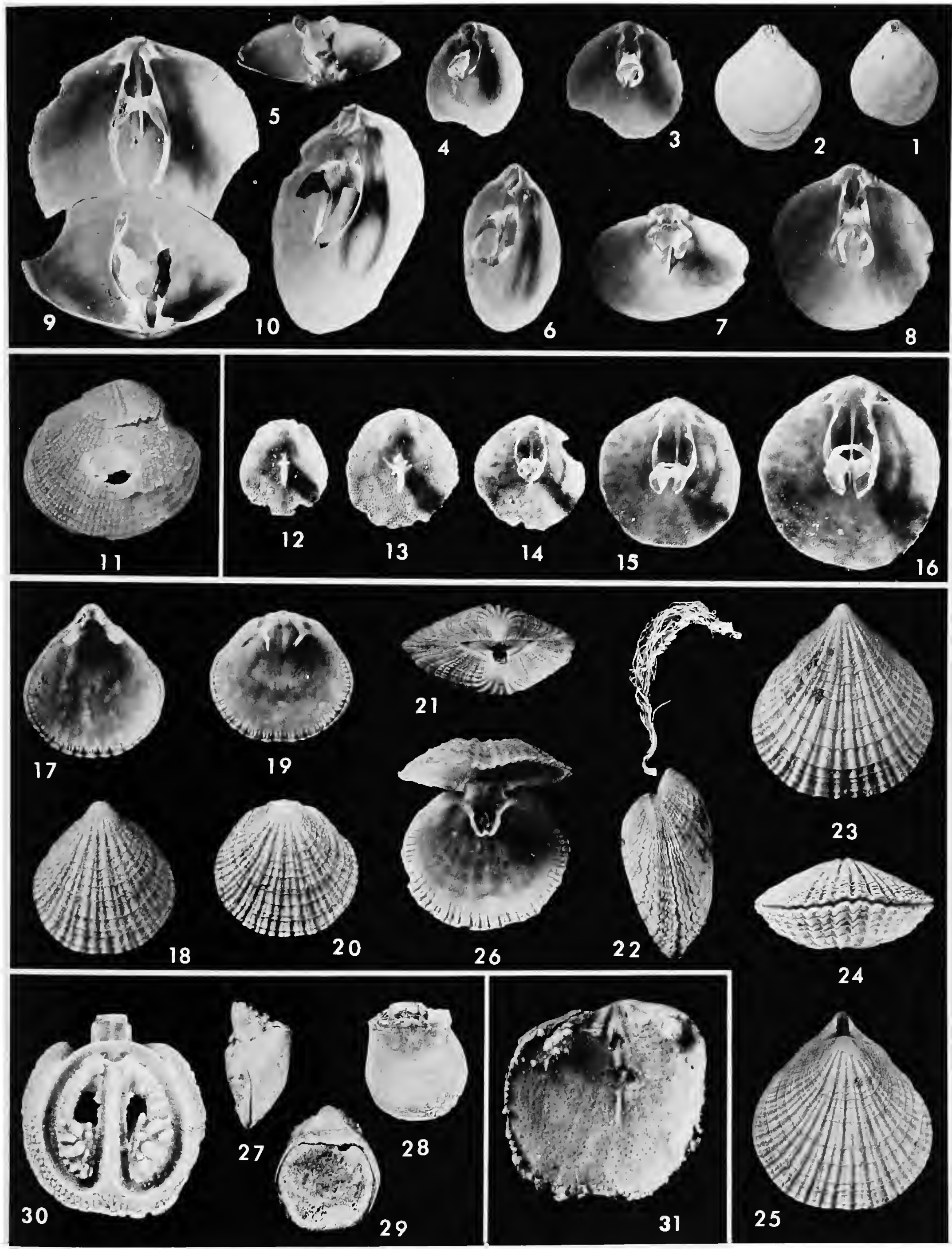

U. S. GOVERNMENT PRINTING OFFICE: 1973-484-322/39 




